\title{
Methyl Jasmonate: Putative Mechanisms of Action on Cancer Cells Cycle, Metabolism, and Apoptosis
}

\author{
Italo Mario Cesari, Erika Carvalho, Mariana Figueiredo Rodrigues, \\ Bruna dos Santos Mendonça, Nivea Dias Amôedo, and Franklin David Rumjanek \\ Laboratório de Bioquímica e Biologia Molecular do Câncer, Instituto de Bioquímica Médica, \\ Universidade Federal do Rio de Janeiro, Avenida Carlos Chagas Filho 373, Prédio CCS, Bloco E, Sala 22, Ilha do Fundão, \\ Cidade Universitária, 21941-902 Rio de Janeiro, RJ, Brazil \\ Correspondence should be addressed to Italo Mario Cesari; italobo2@hotmail.com
}

Received 12 May 2013; Revised 6 November 2013; Accepted 7 November 2013; Published 6 February 2014

Academic Editor: Afshin Samali

Copyright ( 2014 Italo Mario Cesari et al. This is an open access article distributed under the Creative Commons Attribution License, which permits unrestricted use, distribution, and reproduction in any medium, provided the original work is properly cited.

\begin{abstract}
Methyl jasmonate (MJ), an oxylipid that induces defense-related mechanisms in plants, has been shown to be active against cancer cells both in vitro and in vivo, without affecting normal cells. Here we review most of the described MJ activities in an attempt to get an integrated view and better understanding of its multifaceted modes of action. MJ (1) arrests cell cycle, inhibiting cell growth and proliferation, (2) causes cell death through the intrinsic/extrinsic proapoptotic, $\mathrm{p} 53$-independent apoptotic, and nonapoptotic (necrosis) pathways, (3) detaches hexokinase from the voltage-dependent anion channel, dissociating glycolytic and mitochondrial functions, decreasing the mitochondrial membrane potential, favoring cytochrome $c$ release and ATP depletion, activating proapoptotic, and inactivating antiapoptotic proteins, (4) induces reactive oxygen species mediated responses, (5) stimulates MAPKstress signaling and redifferentiation in leukemia cells, (6) inhibits overexpressed proinflammatory enzymes in cancer cells such as aldo-keto reductase 1 and 5-lipoxygenase, and (7) inhibits cell migration and shows antiangiogenic and antimetastatic activities. Finally, MJ may act as a chemosensitizer to some chemotherapics helping to overcome drug resistant. The complete lack of toxicity to normal cells and the rapidity by which $\mathrm{MJ}$ causes damage to cancer cells turn MJ into a promising anticancer agent that can be used alone or in combination with other agents.
\end{abstract}

\section{Introduction}

Cancer cells do not resemble normal cells in terms of morphology and metabolic behavior [1]; under this premise, much effort is invested worldwide in order to develop anticancer therapies that can kill cancer cells without harming normal cells. These therapies attempt to target differentially expressed functional molecules in cancer and normal, nontransformed cells. For this purpose, a myriad of new small molecular weight synthetic and/or natural inhibitor compounds are being tested aiming at achieving selective anticancer clinical treatments. Small molecular weight chemicals from plants (phytochemicals) often accomplish multitargeted anticancer activities including cell cycle arrest, inhibition of cell growth, proliferation, and metastasis and promote apoptosis and cell death [2].
Methyl jasmonate (MJ), our focus in this review, is a natural cyclopentanone lipid (Figure 1) belonging to the jasmonates (JAs) family of plant oxylipin stress hormones (oxygenated fatty acids). JAs originate from $\alpha$-linolenic acid released from the lipid pool of plant cells by lipases and are subsequently oxygenated by lipoxygenases (LOXs) to form hydroperoxide derivatives (cyclopentanones) [3-5]. The JAs family members consist mainly of jasmonic acid (JA), cis-jasmonate (CJ), and MJ [6]. They occur ubiquitously in plants and their production is induced by different types of environmental abiotic (UV radiation, osmotic stress, and temperature variation) and biotic (pathogens, predators) stresses, mediating signaling that triggers defense responses against those stresses [7]. When JAs are synthesized in response to stress, they induced the production of reactive oxygen species (ROS) and of plant secondary metabolites 


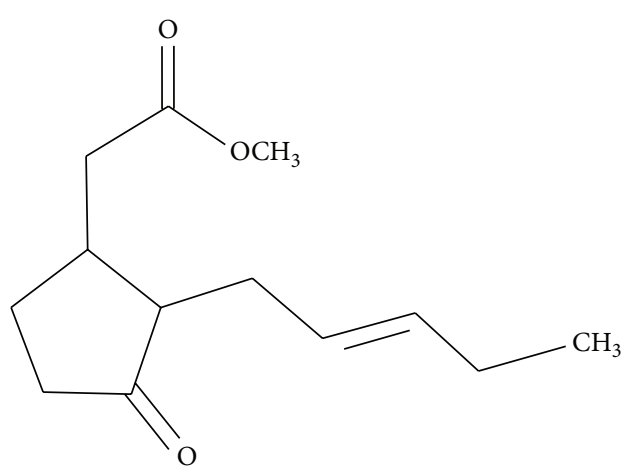

Figure 1: Chemical structure of methyl jasmonate (cyclopentaneaceticacid, 3-oxo-2-(2-penten-1-yl)-, methyl ester).

such as, for instance, phenolic compounds which are used as chemical defenses [6-12]. For instance, ultraviolet- (UV-) B radiation triggers JA accumulation $[10,13]$, whereas $M J$ is produced under herbivore attack and can act as a volatile signal recognized by neighboring plants to induce the synthesis of protease inhibitors [8]. JAs alter plant mitochondrial function and induce reactive oxygen species (ROS) leading to plant cell death in a way similar to mammalian apoptosis $[12,14]$.

MJ has been shown to have powerful anticancer activity through multiple mechanisms [15-24]. The purpose of this review is to gather most relevant findings concerning $\mathrm{MJ}$ mediated anticancer activities in an attempt to integrate them into a functional view that could help us to develop new anticancer research strategies and therapies.

\section{Effects of Jasmonates on Mammalian Cancer Cells}

In 2002, Fingrut and Flescher [15] discovered that MJ strongly and adversely affected human lymphoblastic leukemia cells by suppressing their proliferation and inducing cell death, while nontransformed lymphocytes and normal keratinocytes were unaffected [15]. In these initial studies, they showed that JAs selectively targeted cancer cells in an ex vivo mixed population of leukemic and normal peripheral blood mononuclear cells (PBMCs) from a patient with chronic lymphocytic leukemia (CLL). JAs also increased the life span of T-cell lymphoma-bearing mice [17]. Thereafter JAs, including MJ and related synthetic analogs, were found to inhibit in vitro cancer cell proliferation and to induce cell death in other human and murine cancer cell types $[16,19-24]$, including human breast $[15,25]$, cervix [26-29], colon [30,31], colorectal [32], gastric [33], hepatoma $[34,35]$, lung $[19,36,37]$, lymphoma [15, 17, 18, 38], melanoma $[15,30,39,40]$, myeloid leukemia $[41,42]$, neuroblastoma [43-45], prostate [15, 46-48], and sarcoma [49] cancer cells (Table 1). Other results have shown that JAs and their synthetic derivates exerted selected cytotoxic effects in vivo towards metastatic melanoma $[21,39]$ and inhibited angiogenesis at high doses (it was the reverse at low doses) in the chorioallantoic membrane (CAM) of chicken embryo [40] (Table 2). In general, MJ has been found to be superior to CJ and JA in terms of cytotoxicity and induction of apoptosis in human cancer cells $[33,38,44]$. Independently if jasmonates are dissolved in an organic solvent or not, most experiments in vitro with JAs and MJ have been reported to exert their biological effects at similar low millimolar (mM) concentrations (Tables 1 and 3) excepting few cases where MJ and particularly some of its chemical derivatives were active at micromolar $(\mu \mathrm{M})$ concentrations in vivo (Table 2). Differential dispersion and/or availability of small hydrophobic MJ lipid droplets after phase separation in culture media or solubility in biological fluids in vivo might explain these differences. Nonetheless, JAs have been found to be nontoxic at doses higher than the usual pharmacological doses employed for other compounds (nM, $\mu \mathrm{M}$ ); for instance, an i.v. injection of $236 \mathrm{mg} \mathrm{MJ} / \mathrm{kg}$ body weight in mice (equivalent to $\approx 5.0 \mathrm{mM}$ circulating conc. in a $25 \mathrm{~g}$ adult mouse) was not toxic [15]. The nontoxic i.v. dose was, however, found lower by Reischer et al. in mice $(75 \mathrm{mg} / \mathrm{kg})$ [39]. On the other hand, oral acute toxicity studies performed with MJ on 10 Sherman Wistar rats reported a $\mathrm{LD}_{50}>5 \mathrm{~g} / \mathrm{kg}$, showing a normal necropsy analysis, whereas the dermal acute dose was $\mathrm{LD}_{50}>2 \mathrm{~g} / \mathrm{kg}$ from studies in 10 albino rabbits, showing again a normal necropsy analysis [50]. No skin irritation was observed when MJ was topically applied at $2 \mathrm{~g} / \mathrm{kg}$ to 10 albino rats and at $1 \%$ MJ in 6 albino New Zealand rabbits; similarly, there was no skin irritation when a $10 \% \mathrm{MJ}$ solution was topically applied on 10 guinea pigs and on 50 volunteers (the latter assessed by the Human Repeat Insult Patch Test) [50]. Repeated application of the $10 \% \mathrm{MJ}$ solution at the same skin site in guinea pigs and in 50 volunteers did not show dermal sensitization; neither photoirritation nor photoallergy was observed in the volunteers. No mucosal irritation was observed after a volume of $0.1 \mathrm{~mL}$ of neat MJ was instilled into the right eye of 6 white New Zealand rabbits (left eye served as control) [50]. Finally, when topically applied on cancerous and precancerous skin lesions of eight patients with different pathologies, MJ showed promising results: $3 / 8$ patients with oral lichen planus exhibited positive responses, and $1 / 8$ patient with leukoplakia had complete recovery (for 18 months following the first treatment), while MJ treatment of one patient with lentigo maligna of the face resulted in dry tumor surface with reduction of the metaplastic area during treatment, but the cancer reappeared three months later. MJ did not cause significant local or systemic side effects [51] (Table 2). The notable absence of toxicity of MJ to normal cells and to healthy human and animals at $\mathrm{mM}$ doses indicates that MJ may be used safely in cancer treatments at these doses $[15,19,21,22,38,39,50]$. Furthermore, based in toxicity studies, an exemption from the requirement of a tolerance for MJ was recently published by the US Federal Environmental Protection Agency (EPA) [52]. In this document, MJ was considered as a ubiquitous and naturally occurring plant hormone, regarded as a safe and natural part of the human diet through commonly consumed fruits. No toxicological endpoints were found for MJ through any route of exposure and stated that $\mathrm{MJ}$ is virtually nontoxic to humans and other nontarget organisms, through all routes of exposure, including oral. As further support for these arguments, it was 
TABLE 1: Effect in vitro of natural and synthetic jasmonates on normal and cancer cells.

\begin{tabular}{|c|c|c|c|c|}
\hline Jasmonate & $\begin{array}{l}\text { (JAs conc range) } \\
\text { vehicle }\end{array}$ & Cell lines & Effects & References \\
\hline \multirow{5}{*}{$\mathrm{JA}, \mathrm{MJ}$} & \multirow{5}{*}{$0.5-3.0 \mathrm{mM} / \mathrm{EtOH}$} & $\begin{array}{l}\text { Normal mononuclear cells from } \\
\text { blood (healthy donors) }\end{array}$ & No cytotoxicity & \multirow{5}{*}[15,38]{} \\
\hline & & $\begin{array}{l}\text { Acute human T-lymphoblastic } \\
\text { leukemia Molt- } 4 \text { and } \\
\text { androgen-responsive human } \\
\text { prostate adenocarcinoma LNCap }\end{array}$ & $\begin{array}{l}\text { JA } 3 \mathrm{mM} \text { : } 90 \% \text { cytotoxicity } \\
\text { MJ } 0.5 \mathrm{mM}: 87.5 \% \text { cytotoxicity } \\
\uparrow \text { apoptosis }(\uparrow \text { caspase- } 3 \text { ) } \uparrow \text { necrosis, } \\
\text { PTPC opening, arrest at } \mathrm{G}_{0} / \mathrm{G}_{1}\end{array}$ & \\
\hline & & Human melanoma SK-28 & $\begin{array}{l}\text { JA: } \downarrow \text { proliferation } \\
\text { MJ: } \uparrow \text { cytotoxicity } \uparrow \text { cell death }\end{array}$ & \\
\hline & & Human breast carcinoma MCF-7 & $\begin{array}{l}\text { JA: } \downarrow \text { proliferation } \\
\text { MJ: } \uparrow \text { cytotoxicity } \uparrow \text { cell death }\end{array}$ & \\
\hline & & Murine lymphoma EL-4 & MJ: $\uparrow$ cytotoxicity & \\
\hline MJ & $\begin{array}{c}3.0 \mathrm{mM} \\
\text { no vehicle reported }\end{array}$ & $\begin{array}{l}\text { Acute human T-lymphoblastic } \\
\text { leukemia Molt- } 4\end{array}$ & $\begin{array}{l}\uparrow p 38 \uparrow J N K \uparrow A P-1 \text {, however, } \\
\text { cell death MAPK-independent }\end{array}$ & {$[18]$} \\
\hline $\begin{array}{l}\text { JA, CJ, and } \\
\text { MJ }\end{array}$ & $(\mathrm{mM})$ & Prostate PC-3, HTB-81 & $\downarrow$ proliferation & {$[46]$} \\
\hline MJ & $\begin{array}{c}0.0-0.4 \mathrm{mM} \\
\text { no vehicle reported }\end{array}$ & $\begin{array}{l}\text { Human myeloid } \\
\text { leukemia HL-60 cells }\end{array}$ & $\begin{array}{l}\downarrow \text { cell growth } \uparrow \text { MAPK } \\
\uparrow \text { differentiation to mature cells }\end{array}$ & {$[41]$} \\
\hline $\begin{array}{l}\text { MDDHJ } \\
\text { (synthetic) }\end{array}$ & $\begin{array}{c}0-250 \mu \mathrm{M} \\
\text { no vehicle reported }\end{array}$ & $\begin{array}{l}\text { Human myeloid } \\
\text { leukemia HL-60 cells } \\
\text { Monocytoid leukemia } \\
\text { U937, THP-1 cells } \\
\text { Promyelocytic leukemia } \\
\text { NB4 cells } \\
\text { Lung adenocarcinoma } \\
\text { PC9, PC14 cells }\end{array}$ & $\begin{array}{l}\text { MDDHJ more potent than MJ: } \\
\downarrow \text { cell growth } \uparrow \text { MAPK } \\
\uparrow \text { differentiation to mature cells }\end{array}$ & {$[41]$} \\
\hline MJ & $0.5-5.0 \mathrm{mM}$ & Human lung adenocarcinoma A549 & $\begin{array}{l}\downarrow \text { proliferation } \uparrow \text { ROS } \uparrow \text { apoptosis } \\
(\uparrow \mathrm{Bax} / \mathrm{Bcl}-\mathrm{Xs} \uparrow \text { caspase- } 3)\end{array}$ & {$[36]$} \\
\hline \multirow{4}{*}{$\begin{array}{l}\text { JA, CJ, and } \\
\text { MJ }\end{array}$} & \multirow{4}{*}{$0.5-3.0 \mathrm{mM} / \mathrm{EtOH}$} & $\begin{array}{l}\text { Acute human T-lymphoblastic } \\
\text { leukemia Molt- } 4 \text { cells }\end{array}$ & $\begin{array}{l}\text { Molt- } 4 \text { : } \uparrow \text { mitochondrial membrane } \\
\text { depolarization } \uparrow \text { cyt } c \text { release } \\
\uparrow \text { swelling } \uparrow \text { cell death }\end{array}$ & \multirow{4}{*}[38]{} \\
\hline & & Lymphocytes from CLL patients & $\begin{array}{l}\text { CLL cells: } \uparrow \text { mitochondrial } \\
\text { membrane depolarization } \\
\uparrow \text { cytotoxicity }\end{array}$ & \\
\hline & & Liver carcinoma Hep 3B cells & $\begin{array}{l}\text { Hep3B: } \uparrow \text { mitochondrial membrane } \\
\text { depolarization (PTPC mediated) } \\
\uparrow \text { cyt } c \text { release } \uparrow \text { swelling } \uparrow \text { cell death }\end{array}$ & \\
\hline & & $\begin{array}{l}\text { Human fibroblast } 3 \mathrm{~T} 3 \text { cells } \\
\text { (nontransformed cell line) } \\
\text { Normal blood }\end{array}$ & $\begin{array}{l}\text { Nontransformed } 3 \mathrm{~T} 3 \text { cells: no } \\
\text { cytotoxicity } \\
\text { Normal lymphocytes: no } \\
\text { cytotoxicity }\end{array}$ & \\
\hline \multirow{2}{*}{$\mathrm{JA}, \mathrm{MJ}$} & \multirow{2}{*}{$0.25-3.0 \mathrm{mM} / \mathrm{EtOH}$} & $\begin{array}{l}\text { B-lymphoma clone } \\
\text { 29M6.2 (wild type p53) } \\
\text { B-lymphoma clone }\end{array}$ & $\begin{array}{l}\text { wt p53 cells: } \uparrow \text { apoptosis } \\
\text { mutant p53: } \uparrow \text { nonapoptotic cell } \\
\text { death }\end{array}$ & \multirow[t]{2}{*}[17]{} \\
\hline & & $\begin{array}{l}29 \mathrm{M} 6.10 \text { (mutant p53, resistant to } \\
\text { treatment) }\end{array}$ & $\begin{array}{l}\text { MJ: } \uparrow \sim 90 \% \text { ATP depletion in both } \\
\text { cell types } \\
\text { 2DG, high Glc, but not pyruvate: } \\
\downarrow \text { ATP }\end{array}$ & \\
\hline $\mathrm{CJ}, \mathrm{MJ}$ & $0.5-2.5 \mathrm{mM}$ & $\begin{array}{l}\text { Nonsmall cell lung cancer lines } \\
\text { A549 and H520 }\end{array}$ & $\begin{array}{l}\downarrow \text { proliferation, cell cycle arrest at } \\
\mathrm{G}_{2} / \mathrm{M} \text { phase } \uparrow \mathrm{p} 38 \text { and ERK1/2 } \\
\text { phosphorylation } \uparrow \mathrm{Bax} \uparrow \mathrm{p} 21 \\
\uparrow \text { caspase-3 }\end{array}$ & {$[37]$} \\
\hline
\end{tabular}


TABle 1: Continued.

\begin{tabular}{|c|c|c|c|c|}
\hline Jasmonate & $\begin{array}{l}\text { (JAs conc range) } \\
\text { vehicle }\end{array}$ & Cell lines & Effects & References \\
\hline MJ & $0.5-2.0 \mathrm{mM}$ & $\begin{array}{l}\text { Hormone-refractory prostate } \\
\text { adenocarcinomas PC-3, DU-145 }\end{array}$ & $\downarrow$ proliferation $\uparrow$ apoptosis $\downarrow$ 5-LOX & {$[47]$} \\
\hline MJ & $\begin{array}{c}1-2.6 \mathrm{mM} / \mathrm{EtOH}- \\
\left(\mathrm{IC}_{50}\right)\end{array}$ & $\begin{array}{l}\text { Murine melanoma cells } \\
\text { B16F10 and B16 COL/R } \\
\text { (overexpressing Pgp, MDR) }\end{array}$ & $\downarrow$ cell motility $\downarrow$ cell growth $\downarrow$ MDR & {$[39]$} \\
\hline $\begin{array}{l}\text { TBrJA } \\
\text { (synthetic) }\end{array}$ & $\begin{array}{c}40 \mu \mathrm{M} / \mathrm{EtOH} \\
\text { (MJ doses lower than } \\
\text { in vitro) }\end{array}$ & $\begin{array}{l}\text { Melanoma B16-F10 } \\
\text { Breast MCF-7 } \\
\text { Pancreas Mia PCA-2 } \\
\text { D122, PBL }\end{array}$ & $\uparrow$ citoxicity (TBrJA $\gg \mathrm{MJ})$ & {$[39]$} \\
\hline MJ & $\begin{array}{c}0.5-3.0 \mathrm{mM} \\
\text { no vehicle reported }\end{array}$ & $\begin{array}{l}\text { CT-26 (murine colon carcinoma) } \\
\text { B16 (murine melanoma) } \\
\text { BCL1 (murine B-cell leukemia) } \\
\text { Molt-4 (human T-lymphoblastic } \\
\text { leukemia cell line) }\end{array}$ & $\begin{array}{l}\text { MJ (but not JA) detached } \mathrm{HK} 1 \text { and } \\
\text { HK2 from VDAC1 in isolated } \\
\text { mitochondria from the } \\
\text { four cell lines } \\
\text { MJ did not inhibit HKs activity; } \\
\downarrow \text { ATP } \uparrow c y t c \text { release } \uparrow \text { mitochondria } \\
\text { swelling, } \uparrow \text { cell death }\end{array}$ & {$[20,30]$} \\
\hline MJ & $1.0-2.0 \mathrm{mM}$ & $\begin{array}{l}\text { Human neuroblastoma } \\
\mathrm{BE}(2)-\mathrm{C}\end{array}$ & $\begin{array}{l}\text { Arrest at S-phase } \downarrow \text { cell growth } \\
\downarrow \text { XIAP mRNA } \downarrow \text { survivin mRNA } \\
\uparrow \text { apoptosis }\end{array}$ & {$[43]$} \\
\hline MJ & $0.5-3.0 \mathrm{mM} / \mathrm{DMSO}$ & $\begin{array}{l}\text { Human breast cancer MCF-7 } \\
\text { Human melanocytic MDA-MB- } 435 \\
\text { cells [74] }\end{array}$ & $\begin{array}{l}\text { Arrest at } \mathrm{G}_{0} / \mathrm{G}_{1} \text { and } S \text {-phase } \downarrow \\
\text { membrane fluidity } \uparrow \text { apoptosis: } \\
\text { extrinsic (TNFR1, } \uparrow \text { caspase- } 8 \text { ); } \\
\text { intrinsic }\left[\downarrow \Delta \psi_{m} \uparrow \text { caspase-3 (only }\right. \\
\text { MDA-MB-435)] }\end{array}$ & {$[25]$} \\
\hline $\mathrm{CJ}, \mathrm{MJ}$ & $2.0 \mathrm{mM} / \mathrm{DMSO}$ & $\begin{array}{l}\text { Hormone-independent prostate } \\
\text { PC-3, DU- } 145 \text { cells }\end{array}$ & $\begin{array}{l}\text { Cell cycle arrest } \downarrow \text { cell growth } \\
\uparrow \text { apoptosis } \\
(\uparrow T N F R 1, \uparrow \text { caspase- } 3 \text { ) }\end{array}$ & {$[48]$} \\
\hline \multirow{2}{*}{$\begin{array}{l}\text { JA, CJ, and } \\
\text { MJ }\end{array}$} & \multirow{2}{*}{$1.0-2.0 \mathrm{mM} / \mathrm{DMSO}$} & $\begin{array}{l}\text { Human neuroblastoma } \\
\text { SH-SY5Y }\end{array}$ & $\begin{array}{l}\text { Arrest at } \mathrm{G}_{2} / \mathrm{M} \text { phase } \downarrow \text { cell growth } \\
\uparrow \text { apoptosis }(\downarrow \text { XIAP } \downarrow \text { survivin) } \\
\text { activities: MJ }>\text { JA }>\text { CJ }\end{array}$ & \multirow[t]{2}{*}[44]{} \\
\hline & & $\begin{array}{l}\text { Human embryonic kidney HEK } 293 \\
\text { cells }\end{array}$ & Not affected by MJ & \\
\hline MJ & $1.0-2.0 \mathrm{mM} / \mathrm{DMSO}$ & $\begin{array}{l}\text { Human neuroblastoma } \\
\text { SK-N-SH, BE(2)-C }\end{array}$ & $\begin{array}{l}\text { Arrest at } G_{0} / G_{1} \text { phase } \downarrow \text { cell viability } \\
\downarrow \text { mRNA of PCNA } \uparrow \text { apoptosis } \\
(\downarrow \text { XIAP } \downarrow \text { survivin) }\end{array}$ & {$[45]$} \\
\hline \multirow[t]{2}{*}{ MJ } & \multirow[t]{2}{*}{$0.5-3.0 \mathrm{mM} / \mathrm{EtOH}$} & Sarcomas: MCA-105, & $\begin{array}{l}\uparrow \text { pAkt (correlates with lower } \\
\text { sensitivity to cytotoxicity by } \mathrm{MJ} \text { ) }\end{array}$ & \multirow[t]{2}{*}[49]{} \\
\hline & & SaOS-2 (resistent to MJ) & MJ + 2DG: $\uparrow$ cytotoxicity & \\
\hline MJ & $1.0-5.0 \mathrm{mM} / \mathrm{EtOH}$ & $\begin{array}{l}\text { Cervical cancer SiHA, CaSki, and } \\
\text { HeLa cells: having wt p53 } \\
\text { Cervical cancer C33A cells (with } \\
\text { mutated p53) }\end{array}$ & $\begin{array}{l}\downarrow \text { cell cycle } \uparrow \text { apoptosis through } \\
\text { different pathways } \\
\downarrow \text { ATP } \uparrow \text { lactate (in more glycolytic } \\
\text { CaSki); PARP cleavage, multiple cell } \\
\text { death pathways depending on levels } \\
\text { of p53, p21, Bcl-2, and Bax }\end{array}$ & {$[26]$} \\
\hline $\mathrm{JA}, \mathrm{MJ}$ & $0.25-4.0 \mathrm{mM} / \mathrm{EtOH}$ & $\begin{array}{l}\text { Acute myelogenous leukemia cells } \\
\text { HL- } 60 \text { and KG1 }\end{array}$ & $\begin{array}{l}\uparrow \mathrm{ROS} \uparrow \mathrm{MJ} \text {-induced mitochondrial } \\
\text { membrane depolarization } \\
\uparrow \mathrm{MJ} \text {-induced Mit. SOD } \downarrow \text { AKRC1 }\end{array}$ & {$[132]$} \\
\hline MJ, MDDHJ & $0.15 \mathrm{mM} / \mathrm{DMSO}$ & Leukemia HL-60 cells & $\begin{array}{l}\uparrow \mathrm{Ca}^{2+} \text {-binding protein S100P } \\
\uparrow \text { differentiation } \uparrow \text { regulator of } \\
\text { G-protein signaling-16 (RGS16) }\end{array}$ & {$[42]$} \\
\hline J7 (synthetic) & $\mathrm{IC}_{50} 15 \mu \mathrm{M}$ & $\begin{array}{l}\text { Human cervical carcinoma } \\
\text { HeLa cells }\end{array}$ & $\begin{array}{l}\text { Cell cycle arrest at } G_{2} / \mathrm{M} \text { phase, } \\
\downarrow \mathrm{Bcl}-2 \text { (caspase } 9,3 \text { ) DNA damage }\end{array}$ & {$[27]$} \\
\hline
\end{tabular}


TABle 1: Continued.

\begin{tabular}{|c|c|c|c|c|}
\hline Jasmonate & $\begin{array}{l}\text { (JAs conc range) } \\
\text { vehicle }\end{array}$ & Cell lines & Effects & References \\
\hline J7 (synthetic) & $50 \mu \mathrm{M} / \mathrm{DMSO}$ & Human hepatoma Hep3B & $\begin{array}{l}\uparrow \text { Bax/Bcl-2 ratio } \uparrow \text { DR5 } \uparrow \text { caspase-8 } \\
\downarrow \text { Bid } \uparrow \text { apoptosis correlated with: } \\
\uparrow \text { caspase-9 } \uparrow \text { caspase-3 } \downarrow \text { XIAP } \downarrow \text { cIAP } \\
\downarrow \text { PARP. Extrinsic/intrinsic/MAPK }\end{array}$ & {$[34]$} \\
\hline MJ & $\begin{array}{c}0.5-2.5 \mathrm{mM} \\
\text { no vehicle reported }\end{array}$ & $\begin{array}{l}\text { CD138 } 8^{+} \text {tumor } \\
\text { cells from MM patients }\end{array}$ & $\begin{array}{l}\text { HK2 release from mitochondria, } \\
\text { rapid } \downarrow \text { ATP } \uparrow \text { apoptosis }\end{array}$ & {$[105]$} \\
\hline MJ & $\begin{array}{c}0.25-1.0 \mathrm{mM} \\
\text { no vehicle reported }\end{array}$ & Human colorectal cancer cells CRC & $\begin{array}{l}\uparrow \text { TRAIL } \uparrow \text { cyt } c \text { release } \\
\uparrow \text { caspase cleavage } \downarrow \text { survivin } \\
\downarrow \text { TCF transcriptional activity }\end{array}$ & {$[32]$} \\
\hline MJ & $0.0-2.0 \mathrm{mM} / \mathrm{EtOH}$ & $\begin{array}{l}\text { Cervical cancer cells } \\
\text { SiHa, CaSki, HeLa, and C33A }\end{array}$ & $\begin{array}{l}\uparrow \text { mitochondrial } \mathrm{O}_{2}^{-} \text {(HeLa, CaSki) } \\
\downarrow \text { survivin } \downarrow \text { E6, E7 (HPV) } \\
\uparrow \text { different cell death pathways } \\
\text { (independently of HPV) }\end{array}$ & {$[28]$} \\
\hline J7 (synthetic) & $0-50 \mu \mathrm{M} / \mathrm{DMSO}$ & Human hepatoma HepG2 & $\begin{array}{l}\uparrow \text { ROS } \uparrow \text { TRAIL-mediated apoptosis } \\
\text { ( } \downarrow \text { Bid } \downarrow \text { XIAP } \downarrow \text { cIAP } \downarrow \text { Bcl-xL } \\
\uparrow \text { caspases) }\end{array}$ & {$[35]$} \\
\hline MJ & $\begin{array}{l}3.0 \mathrm{mM}\left(\mathrm{IC}_{50}\right) \text { no } \\
\text { vehicle reported }\end{array}$ & $\begin{array}{l}\text { Human adenocarcinoma colon } \\
\text { HT-39 }\end{array}$ & $\begin{array}{l}\text { Arrest at } \mathrm{S}-\mathrm{G}_{2} / \mathrm{M} \uparrow \text { cytotoxicity } \\
\uparrow \text { apoptosis }\end{array}$ & [31] \\
\hline $\mathrm{JA}, \mathrm{MJ}$ & $1.0-3.0 \mathrm{mM} / \mathrm{DMSO}$ & $\begin{array}{l}\text { Canine macrophagic malignant } \\
\text { DM62 cells }\end{array}$ & $\downarrow$ cell growth $(\mathrm{MJ}>\mathrm{JA}) \uparrow$ cytotoxicity & {$[256]$} \\
\hline MJ & $0.5-0.2 \mathrm{mM} / \mathrm{DMSO}$ & $\begin{array}{l}\text { Human gastric SGC-7901, MKN-45 } \\
\text { cell lines }\end{array}$ & $\begin{array}{l}\downarrow \text { migration } \downarrow \text { invasion } \downarrow \text { angiogenesis } \\
\downarrow \text { MMP-14 }\end{array}$ & {$[33]$} \\
\hline
\end{tabular}

Bcl-2: B-cell lymphoma-2; Bcl-xL: B-cell lymphoma-extra large. Bid: BH3 interacting domain death agonist; cIAP: cellular inhibitor of apoptosis; CJ: cisjasmonic acid; 2DG: 2-deoxy-D-glucose; Glc: glucose; J7: methyl 5-chloro-4,5-didehydrojasmonate; JA: jasmonic acid; NSCLC: nonsmall-cell lung carcinoma; Pgp: P-glycoprotein; MDDHJ: methyl 4,5-didehydro-jasmonate; MDR: multidrug resistance; MMP-14: matrix metalloprotease 14; PARP: poly (ADP-ribose) polymerase; PCNA: proliferating cell nuclear antigen; PTPC: permeability transition pore complex; ROS: reactive oxygen species; S100P: protein SP100; TBrJA: 5,7,9,10-tetrabromo jasmonate; TNFR1: tumor-necrosis factor receptor-1; TRAIL: tumor necrosis factor- (TNF-) related apoptosis-inducing ligand; XIAP: Xlinked inhibitor of apoptosis protein.

TABLE 2: Effect in vivo of natural and synthetic jasmonates derivatives.

\begin{tabular}{|c|c|c|c|c|}
\hline Jasmonates & Conc. range/vehicle & Organism/tissue/cells & Effects & References \\
\hline MJ (oral) & $236 \mathrm{mg} / \mathrm{kg} / \mathrm{lipofundin}$ & Normal C57BL/6 mice & Nontoxic & {$[15]$} \\
\hline MJ (oral) & $236 \mathrm{mg} / \mathrm{kg} / \mathrm{lipofundin}$ & $\begin{array}{l}\text { C57BL/6 mice injected i.p. with } \\
\text { murine T-lymphoma EL-4 }\end{array}$ & $\begin{array}{l}\uparrow \text { survival of treated mice as } \\
\text { compared to the inoculated control }\end{array}$ & {$[15]$} \\
\hline TBrJA & $\begin{array}{c}40 \mu \mathrm{M} / \mathrm{EtOH} \\
\text { (lower doses than } \mathrm{MJ} \\
\text { in vitro) }\end{array}$ & $\begin{array}{l}\text { Murine melanoma } \\
\text { B16-F10 }\end{array}$ & $\downarrow$ lung metastasis & [39] \\
\hline MJ & $1-10 \mu \mathrm{M} / \mathrm{EtOH}$ & Chicken CAM & $\downarrow$ angiogenesis & [40] \\
\hline MJ & $1-10 \mu \mathrm{M} / \mathrm{EtOH}$ & Human endothelial cells (HUVEC) & $\downarrow \mathrm{COX}-2 / \mathrm{PGE}_{2}$ pathway & {$[40]$} \\
\hline MJ (i.p.) & $\begin{array}{l}1 \mathrm{~g} / \mathrm{Kg} \text { in } 0.1 \mathrm{~mL} \\
\text { vegetal oil, i.p. }\end{array}$ & $\begin{array}{l}\text { Multiple myeloma- (MM.1S-) } \\
\text { inoculated } \\
\text { in nod/scid mice }\end{array}$ & $\begin{array}{l}\uparrow \text { survival of treated mice as } \\
\text { compared to the inoculated control }\end{array}$ & {$[105]$} \\
\hline MJ (topical) & $1 \mathrm{~g} / \mathrm{mL}$ oil & $\begin{array}{l}\text { Application on cancerous and } \\
\text { precancerous human skin lesions }\end{array}$ & $\begin{array}{l}\text { No local or systemic side effects; } \\
3 / 8 \text { patients with } \\
\text { positive responses }\end{array}$ & {$[51]$} \\
\hline
\end{tabular}

CAM:chorioallantoic membrane of chicken embryo; HUVEC: human umbilical vein and endothelial cells; TBrJA: synthetic 5, 7, 9, 10-tetrabromo jasmonate.

mentioned that MJ was also assessed and approved by Food and Agriculture Organization/World Health Organization (FAO/WHO) as a food additive. Toxicity results reported in the EPA document [52] were found to agree with those previously published by other groups $[50,51]$.

2.1. Jasmonates (MJ) Can Cause Cancer Cell Cycle Arrest at Different Phases in Different Cancer Cell Types, Inhibiting
Growth and Proliferation. The eucaryotic cell cycle is divided into four phases: $G_{1}, S, G_{2}$, and $M$ that occur in response to growth factors or mitogens. The DNA synthetic (S) and mitotic $(M)$ phases are preceded by gap phases $\left(G_{1}, G_{2}\right)$. Chromosome duplication occurs during $S$ phase; replicated chromosomes are segregated into individual nuclei (mitosis) during $M$ phase and the cell then splits in two. Cell cycle progression can be regulated at $G_{1}, G_{2}$ points by various intracellular and extracellular signals. If extracellular conditions 
TABLE 3: Effect in vitro and in vivo of methyl jasmonate (MJ) combined with other anticancer agents.

\begin{tabular}{|c|c|c|c|c|}
\hline Jasmonate & $\begin{array}{l}\text { Drug conc. } \\
\text { range/vehicle }\end{array}$ & Model & Effects & References \\
\hline $\begin{array}{l}\text { (1) } \mathrm{MJ}+\mathrm{BCNU} \\
\text { (nitrosourea) } \\
\text { in vitro }\end{array}$ & MJ: Fixed conc. & Pancreatic MIA PaCa-1 & $\begin{array}{l}\text { Mitochondriotoxic } \\
\text { synergic cytotoxicity }\end{array}$ & \multirow{3}{*}[170]{} \\
\hline $\begin{array}{l}\text { (2) } \mathrm{MJ}+2 \mathrm{DG} \text {, } \\
\text { adriamycin, taxol, } \\
\mathrm{BCNU} \text { or cisplatin } \\
\text { in vitro }\end{array}$ & $\begin{array}{l}\text { MJ: } \\
0.5-2.0 \mathrm{mM} / \mathrm{EtOH} \\
\text { Taxol, cisplatin: } \\
1-10 \mu \mathrm{g} / \mathrm{mL}\end{array}$ & $\begin{array}{l}\text { CT26, DA-3, GTRAMP C1, MCF7, } \\
\text { MIA PaCa-2, D122, and BCL1 }\end{array}$ & $\begin{array}{l}\text { Strong cooperative } \\
\text { effects of } \mathrm{MJ}+2 \mathrm{DG} \\
\text { and } \mathrm{MJ}+\text { other drugs }\end{array}$ & \\
\hline $\begin{array}{l}\text { (3) } \mathrm{MJ}+\text { adriamycin } \\
\text { in vivo }\end{array}$ & $\begin{array}{l}\text { MJ i.v.: } \\
20-150 \mathrm{mg} / \mathrm{kg} \\
\text { dissolved in } \\
\text { lipofundin. } \\
\text { Adr (DOX) i.p.: } \\
4 \mathrm{mg} / \mathrm{kg}\end{array}$ & $\begin{array}{l}\text { Balb/c mice injected i.p. with } 1 \times 10^{4} \\
\text { chronic BCL1 cells lymphocyte } \\
\text { leukemia cells }\end{array}$ & $\begin{array}{l}\text { MJ + Adr: significant prolonged } \\
\text { survival effect }\end{array}$ & \\
\hline $\begin{array}{l}\text { (4) } \mathrm{MJ}+\mathrm{PI} 3 \mathrm{~K} / \mathrm{Akt} \\
\text { inhibitors } \\
\text { in vitro }\end{array}$ & $\begin{array}{l}\text { MJ: } 0.5-3.0 \mathrm{mM} \\
\text { EtOH/DMSO }\end{array}$ & Sarcoma MCA-105, SaOS-2 & $\begin{array}{l}\downarrow \text { MJ-induced activation of Akt } \\
\uparrow \text { synergic cytotoxicity }\end{array}$ & \multirow[t]{2}{*}[49]{} \\
\hline $\begin{array}{l}\text { (5) } \mathrm{MJ}+2 \mathrm{DG} \\
\text { in vitro }\end{array}$ & $\begin{array}{l}\text { MJ: } 0.5-3.0 \mathrm{mM} \\
\text { EtOH/DMSO }\end{array}$ & Sarcoma MCA-105, SaOS-2 & $\begin{array}{l}\text { 2DG: } \downarrow \text { pAkt, } \downarrow \text { MJ-ind. pAkt } \\
\text { MJ + 2DG: } \uparrow \text { synergic cytotoxicity }\end{array}$ & \\
\hline $\begin{array}{l}\text { (6) } \mathrm{MJ}+\text { irradiation } \\
\text { in vitro }\end{array}$ & $\begin{array}{l}0.5-2.0 \mathrm{mM} \\
\text { DMSO }\end{array}$ & $\begin{array}{l}\text { Irradiated prostate PC-3 (radiation } \\
\text { induces Bcl-2 expression) }\end{array}$ & $\begin{array}{l}\downarrow \text { radiation-induced Bcl-2 } \\
\uparrow \text { radiation sensitivity PC-3 } \\
\uparrow \text { caspase-3 }\end{array}$ & {$[104]$} \\
\hline $\begin{array}{l}\text { (7) } \mathrm{MJ} \text { and/or } \mathrm{POH} \\
\text { and/or } \\
\text { cis-platin }(\mathrm{CP}) \\
\text { in vitro }\end{array}$ & $\begin{array}{l}\text { Both tested } \\
\text { at } \mathrm{IC}_{20}\end{array}$ & $\begin{array}{l}\text { Human MDA-MB- } 435 \\
{[74]} \\
\text { Human breast } \\
\text { MDA-MB-231 }\end{array}$ & $\begin{array}{l}\text { MJ }+ \text { POH: } \uparrow \text { TNFR } 1 \\
\downarrow \Delta \psi_{m} \uparrow \text { cytotoxicity; cell cycle arrest } \\
\text { at } G_{0} / G_{1} \uparrow \text { apoptosis } \\
+\mathrm{CP} \text { : all effects enhanced } \\
\uparrow \text { apoptosis }\end{array}$ & {$[251]$} \\
\hline $\begin{array}{l}\text { (8) } \mathrm{MJ}+\mathrm{TRAIL} \\
\text { in vitro }\end{array}$ & $\begin{array}{l}\text { MJ } 0.5 \mathrm{mM}+ \\
\text { TRAIL } \\
\left(100-200 \mathrm{ng} \cdot \mathrm{mL}^{-1}\right)\end{array}$ & CRC cancer cells & $\begin{array}{l}\downarrow \text { survivin (IAP) } \\
\downarrow \text { Wnt/TCF pathway } \\
\uparrow \text { TRAIL-induced apoptosis } \\
\uparrow \text { caspase activity }\end{array}$ & {$[32]$} \\
\hline $\begin{array}{l}\text { (9) } \mathrm{MJ}+\mathrm{Smac} \\
\text { in vitro }\end{array}$ & $\begin{array}{l}\text { MJ: } 0.5-2.0 \mathrm{mM} \\
\text { DMSO }\end{array}$ & $\begin{array}{l}\text { Human bladder cancer EJ, T24 } \\
\text { Human embryonic kidney HEK } \\
293\end{array}$ & $\begin{array}{l}\text { Synergy: } \uparrow \text { IAPs-bound caspase } 3 \\
\text { †apoptosis } \\
\text { No cytotoxicity }\end{array}$ & {$[254]$} \\
\hline $\begin{array}{l}\text { (10) } \mathrm{MJ}+\text { Smac7N } \\
\text { (IAP antagonist) } \\
\text { in vitro }\end{array}$ & $\begin{array}{l}\text { MJ: } 0.5-2.0 \mathrm{mM} \\
\text { DMSO }\end{array}$ & $\begin{array}{l}\text { Hormone-independent prostate } \\
\text { DU-145, PC-3 } \\
\text { Human proximal tubular epithelial } \\
\text { HK-2 cells (overexpressing IAPs) }\end{array}$ & $\begin{array}{l}\text { Smac7N: } \uparrow \mathrm{MJ} \text {-induced apoptosis by } \\
\text { caspase-9-dependent (intrinsic) and } \\
\text { independent (extrinsic) pathways }\end{array}$ & {$[255]$} \\
\hline $\begin{array}{l}\text { (11) } \mathrm{MJ}+\text { cisplatin } \\
(0.1-0.5 \mu \mathrm{M}) \\
\mathrm{MJ}+\mathrm{X} \text {-rays } \\
(0.25-3 \mathrm{~Gy}) \\
\mathrm{MJ}+\alpha \text {-rays } \\
\end{array}$ & $\begin{array}{l}\text { MJ: } 0.1-1.0 \mathrm{mM} \\
\text { EtOH }\end{array}$ & $\begin{array}{l}\text { Cervical cancer cells } \\
\text { SiHa, CaSki, HeLa, and C33A }\end{array}$ & $\begin{array}{l}\downarrow \text { viability } \\
\downarrow \text { survival } \\
\downarrow \mathrm{IC}_{50} \text { radiation dose }\end{array}$ & {$[29]$} \\
\hline $\begin{array}{l}\text { (12) } \mathrm{MJ}+5-\mathrm{FU} \\
\text { in vitro }\end{array}$ & $\begin{array}{l}0.5 \mathrm{mM} \mathrm{MJ} / 1 \mathrm{~h} \text {, } \\
\text { then + 5-FU }\end{array}$ & $\begin{array}{l}\text { Human adenocarcinoma } \\
\text { colon HT-39 }\end{array}$ & $\downarrow \mathrm{IC}_{50} 5-\mathrm{FU}(5 \rightarrow 2.5 \mathrm{mM})$ & {$[31]$} \\
\hline
\end{tabular}

BCNU: 1,3-bis-(2-chloroethyl)-1-nitrosourea; 2DG: 2-deoxy-D-glucose; 5-FU: 5-fluorouracile; IAP: inhibitors of apoptosis; MM: multiple myeloma; POH: perillyl alcohol; smac: second mitochondria-derived activator of caspases; Smac7N: a peptide that contains the N-terminal seven residues of smac; TNFR1: tumor-necrosis factor receptor-1; TRAIL: tumor necrosis factor- (TNF-) related apoptosis-inducing ligand.

are unfavorable, cells delay progress through $\mathrm{G}_{1}$ and may enter a quiescent state known as $\mathrm{G}_{0}$, in which they can remain for days, weeks, or years before resuming proliferation. If extracellular conditions are favorable and signals to grow and divide are present, cells in early $G_{1}$ or $G_{0}$ progress through a restriction checkpoint late in $G_{1}$ after which cells are committed to DNA replication even if the extracellular signals that stimulate cell growth and division are removed $[53,54]$. Cell cycle activity is modulated by intracellular ROS levels and regulates cell survival, cell proliferation, and apoptosis [53-58]. The progression through the $G_{1}, S, G_{2}$, and $\mathrm{M}$ phases is promoted by cyclin-dependent kinases (CDKs), 
which are positively and negatively regulated by cyclins and cyclin kinase inhibitors (CKis), respectively, and by ROS. Unlike the passage through the $S, G_{2}$, and $M$ phases, $G_{1}$ progression normally relies on stimulation by mitogens and can be blocked by antiproliferative factors; passage through the restriction checkpoint and entry into $S$ phase is controlled by CDKs that are sequentially regulated by cyclins $\mathrm{D}, \mathrm{E}$, and $\mathrm{A}[53,54,56-58]$. In general, $\mathrm{CDK}$ activity requires cyclin binding and depends on both positive and negative regulatory phosphorylations [54]. ROS levels influence the phosphorylating and ubiquitinating enzyme activites, thus controlling cell cycle progression $[54,57,58]$.

A master gene regulating cell passage through the cycle is the Myc family of transcription factors; it switches on the simultaneous synthesis of thousands of different proteins required for cell growth and cell cycle function $[58,59]$. To counteract Myc protein activity, the cell cycle is also regulated by the p53 protein $[60,61]$, a DNA-binding transcription factor that senses DNA damage (occurring after exposure to ionizing radiation, UV light, oxidative stress, or other DNA damaging agents) and activates genes to halt cell cycle progression in $G_{1}$ for repair, or otherwise initiates apoptosis $[56,62]$. When the damage caused by cell stress is mild, p53 activates mechanisms for cell cycle arrest and repair damaged DNA; if the damage is irreparable, p53 initiates apoptosis [63]. In case of mild cellular stress, low levels of p 53 can activate the TP53-induced glycolysis and apoptosis regulator (TIGAR) gene that decreases the rate of glycolysis and hence ROS levels in the cell [64]. Glycolysis is essential for cancer progression, but TIGAR provides protection from ROS and apoptosis. However, if damage caused by stress is irreparable, p53 prevents proliferation of cells with altered DNA and induces increased levels of ROS to trigger cell death [56]. Increased levels of active p53 inhibit the cell entry into the S-phase or induce apoptosis [56]. Loss or inactivation of p53 results in loss of cell-cycle arrest or inhibition of apoptosis after DNA damage or physiological stress [65] leading to increased genetic instability, increased accumulation of mutations, and ultimately oncogenesis [61]. When the cell cycle is no longer regulated by $\mathrm{p} 53$, cells remain cycling (supported by $c$-Myc overexpression), subverting cell cycle exit, maturation, and terminal differentiation [66]. Over 50\% of all human cancers harbor mutations and genetic alterations in cyclins and p53 genes directly affecting the function of critical cell cycle proteins, rendering the $p 53$ gene ineffective in mediating cell growth arrest and promoting cancer cell death $[62,67,68]$. ROS production is under p53 regulation, and in turn p53, being a redox-sensitive protein, is influenced by ROS levels; thus, ROS can act as both an upstream signal that triggers p53 activation and as a downstream factor that mediates apoptosis [69]. Thus, mutations in the $p 53$ gene downregulate its activity and, consequently, ROS production [70]. Through ROS, p53 can also directly control metabolic traits of cells [71], regulate mitochondrial membrane potential $\left(\Delta \psi_{m}\right)$, and induce cytochrome $c$-independent apoptosis (blocked by Bcl2); ROS-mediated disruption of $\Delta \psi_{m}$ constitutes a pivotal step in the apoptotic pathway of p53, and this pathway does not involve cytochrome $c$ release [72]. ROS can thus regulate cell fate through p53, in a way that physiological ROS levels trigger cell protective pathways, while under cytotoxic oxidative stress p53 behaves more like a cell killer [70,73].

JAs (mainly MJ) have been found to arrest cell cycle of different cancer cell types at different phases (Table 1): $G_{0} / G_{1}$, in human acute lymphoblastic leukemia Molt-4 $[14,38]$ and human neuroblastoma SK-N-SH, BE(2)-C [45]; $\mathrm{G}_{0} / \mathrm{G}_{1}-\mathrm{S}$ in human breast MCF-7 and melanocytic MDA-MB- 435 cancer cells [25, 74]; S, in human neuroblastoma BE(2)-C [43]; S$\mathrm{G}_{2} / \mathrm{M}$, in human adenocarcinoma colon HT-39 [31]; $\mathrm{G}_{2} / \mathrm{M}$, in nonsmall cell lung cancer (NSCLC) lines A549 and H520 [37], human neuroblastoma SH-SY5Y [44], human cervical carcinoma, and HeLa cells [27]. At $0.1 \mathrm{mM}, \mathrm{MJ}$ arrested in vitro human umbilical vein endothelial cells (HUVEC) at $\mathrm{G}_{1}$ [40].

The molecular mechanisms underlying the above jasmonate-mediated cell cycle arrest in cancer and embryonic HUVEC cells in vitro are not yet completely understood. Checking the above data against the UMD TP53 mutation database (http://www.p53.fr/) and revising the article by Berglind et al. [75], we could not find correlation between a given MJ-mediated phase arrest of cell cycle and the TP53 wild type or mutated status of a cancer cell type (data not shown), a result that would agree with the original observation of Fingrut and Flescher [15] stating that MJ-mediated cell death is independent of the p53 status [17]. However, other studies suggest that $\mathrm{MJ}$ could be acting by interfering different cell cycle regulatory mechanisms. In plants, $\mathrm{MJ}$ is able to bind the TGACCG motif which is present in cell cycle cyclin promoters [76]; we might speculate MJ recognition of TGACCGlike motifs in mammalian cells cyclin promoters; however, this would need experimental confirmation. In some plants, MJ impairs the $\mathrm{G}_{2}$-to-M transition by repressing $\mathrm{M}$-phase gene activation [77]. $\mathrm{MJ}$ impaired the $\mathrm{G}_{2}$-to-M transition in the human neuroblastoma SH-SY5Y cells, downregulating the expressions of the proliferating cell nuclear antigen (PCNA, a processivity factor encircling DNA at sites of replication and repair) and N-Myc [45]. As mentioned above, MYC is the master gene allowing cancer cells to move along the cell cycle and regulating most genes needed to meet the metabolic demands for cell proliferation and survival [78]. Cancer cell cycle arrest at different phases is in itself closely dependent on the cell energy and as such it is extremely dependent on metabolic ATP availability and its use by hexokinase. Downregulation of Myc by MJ [45] is interesting result that must be confirmed, particularly because there is a lack of specific inhibitors against Myc [57].

In some cases of cell cycle arrest, MJs have been found to upregulate p21 [37] whereas in others to downregulate survivin mRNA and protein levels [43-45] (Table 1). Survivin is an important member of the inhibitor of apoptosis protein (IAP) family that also regulates entrance of the cell cycle to the $\mathrm{M}$ phase and is overexpressed in cancer cells acting linking both regulation of the cell cycle and inhibition of apoptosis [79].

2.2. Jasmonates (MJ) Can Cause Cancer Cell Death by Inducing Apoptosis and/or Necrosis. Apoptosis can be initiated by two signaling cascades, namely, the extrinsic and the intrinsic 
pathway. The classical extrinsic pathway is triggered by the binding of extracellular signals like tumor necrosis factor (TNF), tumor necrosis factor-related apoptosis-inducing ligand (TRAIL), and apoptosis antigen-1 (Fas) ligand (FASL) to death receptors such as tumor necrosis factor receptor 1 (TNFR1) and FAS [80]. This interaction leads to procaspase-8 activation which cleaves itself into caspase- 8 . Then, caspase- 8 can cleave and activate procaspase- 3 into caspase- 3 that cleaves many substrates inside the cell inducing the typical morphological changes seen in apoptosis. The intrinsic pathway can be triggered by intracellular stress signals, such as oxidative stress and DNA damage. The diverse signals are sensed by mitochondria through the balance between proand antiapoptotic members of the Bcl-2 family of proteins. When proapoptotic signals overcome antiapoptotic signals, mitochondria become permeabilized leading to dissipation of the mitochondrial electrochemical potential, release of intermembrane proteins like cytochrome $c$, Smac/DIABLO, AIF, and HTRA2/OMI. Cytochrome $c$ interacts with procaspase- 9 and Apaf-1 to form the apoptosome complex that leads to caspase-3 activation [81]. The extrinsic pathway can connect with the intrinsic pathway through the cleavage by caspase- 8 of Bid into tBid (truncated Bid), which is a proapoptotic member of the Bcl-2 family and can lead to mitochondria permeabilization $[82,83]$. The members of the Bcl-2 family regulate mitochondria permeabilization and comprises antiapoptotic (Bcl-2, Bcl-xL), proapoptotic (Bax, Bak), and proapoptotic $\mathrm{BH}-3$ only proteins (Bad, Bid, Puma, and Noxa) [82-84]. One of the mechanisms of mitochondria permeabilization is controlled by Bax and Bak proteins that are normally expressed in every cell but are maintained inhibited by the antiapoptotic members. When there is a signal to apoptosis, $\mathrm{BH} 3$-only proteins interact with the antiapoptotic members, releasing Bax/Bak or directly activating them, leading to their oligomerization and to mitochondrial outer membrane permeabilization (MOMP). Another mechanism for mitochondria permeabilization is the formation of the mitochondrial permeability transition (MPT) pore which is composed by the voltage-dependent anion channel VDAC, the adenine nucleotide translocase (ANT), and cyclophilin D [85]. The MPT pore, comprising VDAC1, is directly regulated by $\mathrm{Bad}[86]$. In contrast, VDAC2 has been identified as an antiapoptotic, negative regulator of Bak [87-89].

One of the hallmarks of cancer is resistance to cell death [90]. This resistance is acquired by a host of different genetic defects in cancer cells, such as those present in the p53 tumor suppressor gene $[62,68,91]$. Normal p53 responds to genotoxic, oncogenic, and other stress signals by inducing antiproliferative transcriptional programs leading to growth arrest (for cell repair) or apoptosis [92]. p53 mediates cycle arrest by transcriptionally activating the $p 21$ (CDKN1A), 143-3 $\sigma$ (SFN), and GADD $45 \alpha$ genes, whereas p53-dependent apoptosis is triggered by turning on the synthesis of proteins that produce $\operatorname{ROS}[58,93]$ and transactivating different mitochondrial proapoptotic genes as well as death receptors for the synthesis of the corresponding proteins $[58,94]$. When p53 (and its target genes) expression levels are below a threshold, they induce cell cycle arrest but not apoptosis; above this threshold, p53 trigger apoptosis [95]. Lowering this threshold with inhibitors of the antiapoptotic Bcl-2 family proteins sensitize cells to p53-induced apoptosis [95]. By damaging cells, chemotherapeutical drugs turn on p53's transcriptional function that upregulates the expression of proapoptotic proteins. Defects in the p53 function or in the apoptotic cascades lead to cell phenotypes resistant to chemotherapy. Apoptosis can also be induced by anticancer agents independently of p53 by either directly modulating the apoptotic machinery or directly interacting with mitochondria [96]. ROS levels might be playing a central role in mediating various forms of nonapoptotic, caspase-independent, programmed cell death either through direct irreversible oxidative damage to key proteins, nucleic acid molecules, and cellular structure or by the activation of prodeath signal transduction programs [97]. In a ROS-dependent nonapoptotic cell death pathway, respiration through the mitochondrial electron transport system (ETS) chain is not essential and ROS is generated through NADPH oxidases [97]. In contrast to the mitochondrial ETS which generates ROS as a byproduct of respiration, NADPH oxidases produce ROS as their primary function [98]. Raise of ROS is characteristic after ionizing radiation, chemotherapy, and targeted therapy treatments $[58,99]$ and may be killing cancer cells through a nonapoptotic ROS-dependent cell death pathway.

Tumor cells maintain high ATP/ADP as well as $\mathrm{NADH} / \mathrm{NAD}^{+}$ratios, so as to assure that ATP levels are never limited; ATP depletion would represent then an unsustainable metabolic stress for tumor cells and it is associated with necrotic death in some cell types [100]. Recently, it was shown that a signaling cascade centered on the proteins RIP1 and RIP3 can trigger cell death by necrosis in many situations, and the RIP1-RIP3 complex appears to promote ATP depletion during necroptosis by impinging on components of the MPT pore $[101,102]$. Necrosis was a term used to describe a process of accidental cell death, in which cells swell and burst releasing its intracellular content, whereas necroptosis modernly refers rather to an ordered cell death program different from apoptosis; apoptosis is a caspase-dependent cell death process, whereas necrosis is caspase-independent process $[102,103]$. Studies concerning necrosis have focused mainly on cell membrane permeability to propidium iodide (PI) in the flow citometry double staining with annexin-V/PI.

Fingrut et al. [17] by studying the effect of MJ on two clones of a highly malignant B-cell lymphoma (one harboring a normal wild type (wt) p53 gene, while the other expressed a mutated, inactive $\mathrm{p} 53$ protein) (Table 1) reported that $\mathrm{MJ}$ was equally toxic to both clones [17]. In contrast, the p53-mutant cells were resistant to radiomimetics (drugs having effects similar to those produced in radiotherapy) and chemotherapeutic drugs. In this cancer cell model, MJ induced mostly apoptotic cell death in the wt p53-expressing lymphoma cells, while no signs of early apoptosis were detected in the mutant $p 53$-expressing lymphoma cells that were killed by $\mathrm{MJ}$ through a $\mathrm{p} 53$-independent, nonapoptotic cell death mechanism. However, other cancer cell types can undergo apoptosis with or without functional p53, and as we will see, MJ can induce apoptotic and/or nonapoptotic cell death in wt p53 as well as in TP53 mutated cells 
(Table 1). Nonapoptotic cell death could be the consequence of the severe bioenergetic damages induced by the direct interaction of MJ with mitochondria, leading to increased ROS levels, inhibition of ATP synthesis, and ATP depletion $[20,30]$. Jasmonates, including MJ and some of its analogs, have been found to be strongly proapoptotic in vitro in different types of cancer cells, by both the extrinsic and the intrinsic pathway (Table 1), with no or little cytotoxicity to normal cells $[15,25,36,37,44,45]$. Thus, MJ induced the expression of TNFR1 in human breast MCF-7 and MDAMB-435 cells $[25,74]$ and in hormone-independent human prostate PC-3 and DU 145 cancer cells promoting apoptosis by the extrinsic pathway in these cells [48]. TRAIL (TNFrelated apoptosis inducing ligand) is able to induce apoptosis in prostate cancer cell, yet overexpression of antiapoptotic proteins and inhibition of proapoptotic proteins results in diminishing the TRAIL-mediated apoptosis pathway. TRAIL has emerged as a potent anticancer agent in laboratorybased studies and preclinical trials, and JAs have been found to sensitize cancer cells to TRAIL-mediated apoptosis [32] (Table 3). J7, a synthetic analogue of MJ, enhanced TRAILmediated apoptosis through upregulation of ROS levels in human hepatoma HepG2 cells; apoptosis was induced via Bid cleavage, downregulation of X-linked inhibitor of apoptosis protein (XIAP), cellular inhibitor of apoptosis-1 (cIAP-1), $\mathrm{B}$-cell lymphoma-extra large (Bcl-xL), and activation of caspases [35]. Other examples of MJ-mediated apoptotic and/or nonapoptotic cell death in different cancer cell types (Table 1) are as follows: (1) MJ induced ROS production in A549 lung adenocarcinoma cells, activating Bcl-2-associated$\mathrm{X}$-protein (Bax) as well as Bcl-2-Like-1 (Bcl2L1) proapoptotic proteins in these cells [36]; (2) MJ activated caspase-3 in leukemia Molt-4, prostate SK28, and LNCaP cancer cells [15]; (3) MJ inhibited the antiapoptotic Bcl-2 protein and enhanced proapoptotic proteins in radio-resistant human prostate cancer cell line PC-3 [104]; (4) MJ suppressed the proliferation of the neuroblastoma cell lines SH-SY5Y, SK$\mathrm{N}-\mathrm{SH}$ and $\mathrm{BE}(2)-\mathrm{C}$ through a strong apoptosis-inducing effect, as measured by annexin VFITC/PI; MJ treatment also downregulated the expression of the antiapoptotic proteins XIAP and survivin $[44,45]$; (5) MJ-mediated cell death was observed on cervical cancer and myeloma cells and it was reported to be due to mixed characteristics of apoptosis and necrosis $[26,105]$. So far, studies showing MJ inducing the RIP1 signaling cascade have not been reported; however, it will be important to deep into these analyses to clear distinguish between MJ-induced apoptosis and/or necrosis.

\subsection{Methyl Jasmonate Induces the Production of Reactive} Oxygen Species (ROS) Responses in Some Cancer Cell Types Leading Also to Cell Death. Intracellular ROS levels regulate cell cycle activity, cell metabolism and survival, cell proliferation, and apoptosis [53-58]. Stressful conditions produce a transient excess of intracellular ROS in normal tissues; however, under chronic pathological and oxidative stress conditions, ROS is continuously produced in excess and persistently, causing damage to DNA, cell membranes, lipids, proteins, and inducing apoptosis; to control and avoid oxidative damages, cells counteract excess ROS by enzymatic (superoxide dismutase (SOD), glutathione peroxidase (GPx), and catalase) and/or nonenzymatic (glutathione, thoredoxin) antioxidant elements $[99,106]$. Controlling ROS is central to intracellular redox signaling and homeostasis; on the other hand, uncontrolled/unbalanced ROS production modifies intracellular redox leading to apoptosis $[58,82,99,106]$. ROS can be generated by different biological systems: (1) direct or indirect extracellular stimulation of plasma membranebound $\mathrm{NAD}(\mathrm{P}) \mathrm{H}$ oxidases (NOX) can generate intracellular $\mathrm{H}_{2} \mathrm{O}_{2}$ [57, 107-110]; (2) biochemical pathways associated to fatty acid oxidation, and lipoxygenases activities generate ROS as normal byproducts of these activities [111]; (3) ATP generation by oxidative phosphorylation (OxPhos) in mitochondria is accompanied by the production of ROS as a consequence of electron leakage from the electron transport chain; mitochondria are considered to be major sources of ROS in mammalian cells particularly under a variety of stressful conditions $[82,99]$. Superoxide $\left(\mathrm{O}_{2}{ }^{-}\right)$is mainly produced from complexes I and III and it is rapidly dismutated to $\mathrm{H}_{2} \mathrm{O}_{2}$ and oxygen by SOD [112]. $\mathrm{H}_{2} \mathrm{O}_{2}$ serves both as a toxic oxidant and as an essential signaling molecule regulating cellular biological processes [113]. A strong positive correlation exists between mitochondrial membrane potential $\left(\Delta \psi_{m}\right)$ and ROS production $[106,114,115]$. Mitochondria produce more ROS at high membrane potential, and an increase in the $\Delta \psi_{m}$ produced either by a closure of MPT pore or by inhibition of the ATP synthase is associated with increased ROS production. However, in cases of mitochondrial dysfunctions, low $\Delta \psi_{m}$ and decreased activity of the respiratory chain are accompanied by a simultaneous increase in ROS [116, 117]. It has been reported that cancer cells have higher ROS content compared to normal cells $[118,119]$ probably due to abnormal respiration because of dysfunctional mutations in mitochondria [120], but they also have increased contents of antioxidants (SOD, catalase, glutathione, thioredoxin, etc.) to counteract $\operatorname{ROS}[58,121]$. Tumor cells cannot tolerate excessive high ROS levels $[118,122]$ and as a matter of fact, radiation therapy, chemotherapies, and targeted therapies induce apoptosis and kill some cancer cells by generating excess $\operatorname{ROS}[99,106,123,124]$. Thus, inducing higher levels of ROS in cancers cells can be exploited as an effective selective strategy to kill tumor cells over normal cells [119]. However, prolonged treatment with the same drug reduces ROS levels in cancer cells [124], indicating that when they become drug-resistant, tumor cells have lower ROS content than drug-sensitive cancer cells. Evidence suggests that drugresistant cells have a higher expression of catalase at the plasma membrane that keeps reduced ROS levels [121].

In plants, MJ-mediated damage to mitochondria is followed by a rapid production of $\mathrm{H}_{2} \mathrm{O}_{2}$ [125]. $\mathrm{H}_{2} \mathrm{O}_{2}$ is used as a second messenger for the induction of genes and products related to defense against both herbivores and pathogens [126]; in addition, $\mathrm{H}_{2} \mathrm{O}_{2}$ induces apoptosis and senescence $[127,128]$. On the other hand, it has been signaled that the MJ-induced production of $\mathrm{H}_{2} \mathrm{O}_{2}$ in plants was prevented by inhibitors of $\mathrm{NAD}(\mathrm{P}) \mathrm{H}$ oxidase $[128,129]$ indicating another mechanism of MJ-mediated production of ROS and a major role for this enzyme in MJ-induced ROS responses. MJ 
induces also an endogenous $\mathrm{H}_{2} \mathrm{O}_{2}$ response in some cancer cell lines (Table 1) [19, 36, 38, 130-132]. In A549 cancer lung cells, the $\mathrm{H}_{2} \mathrm{O}_{2}$ response induced by $\mathrm{MJ}$ increased the expression of the proapoptotic Bax and Bcl-Xs (although not being that of the antiapoptotic $\mathrm{Bcl}-2$ and $\mathrm{Bcl}-\mathrm{xL}$ proteins) and this led to apoptosis; this event was inhibited by catalase (a specific inhibitor of $\mathrm{H}_{2} \mathrm{O}_{2}$ ) [36]. MJ increased the intracellular levels of $\mathrm{H}_{2} \mathrm{O}_{2}$ and superoxide $\left(\mathrm{O}_{2}\right)$ ions in human $\mathrm{C} 6$ glioma cells in vitro and induced the expression of heat shock protein 72 ( $\mathrm{HSP} 72$ ), a negative regulator of $\mathrm{H}_{2} \mathrm{O}_{2}$-induced oxidative stress, in these cells in vitro; MJ-induced HSP72 expression was blocked by ROS inhibitors [130]. Elevated ROS generation was observed in response to both $\mathrm{MJ}$ and JA levels in the acute myeloid leukemia HL-60 and KGla cell lines; but other factors, like the MJ-mediated generation of mitochondrial SOD rather than ROS were determinant for apoptosis or differentiation in these cells [132]. Suppression of $\mathrm{MJ}$-induced apoptosis by antioxidants like $\mathrm{N}$-acetylcysteine (NAC) and catalase, but not by inhibitors of hydroxyl radicals and superoxide ions, indicates that $\mathrm{H}_{2} \mathrm{O}_{2}$ is nonetheless one of the important factors involved in MJ anticancer effects [19].

2.4. By Dissociating Hexokinase (HK) from the Voltage Dependent Anion Channel (VDAC) on the Outer Mitochondrial Membrane, MJ Dissociates Glycolysis from Oxidative Phosphorylation Causing Severe Bioenergetic Deregulations in Cancer Cells. Metabolism and cell growth are two cellular processes that are tighly linked and regulated [133]. The classic bioenergetics phenotype of cancer cells of enhanced glycolysis under aerobic conditions was described by Warburg [134]. However, the "Warburg effect" does not necessarily imply mitochondrial dysfunction [135]. To increase glycolysis, cancer cells upregulate the transcription of genes involved in the glycolytic pathway (i.e., glucose transporters, glycolytic enzymes, etc.). This metabolic reprogramming allows increased rate of ATP production, synthesis of lipids, and a new redox balance. Cancer cells actually use a combination of both glycolysis and mitochondrial respiration to produce energy, and they may vary in regards to the preferential use of these pathways, being in some cases either more glycolytic/less oxidative or less glycolytic/more oxidative, depending on the prevalent normoxic or hypoxic environmental conditions and their capacities to express adequate levels of oncogenes and tumor suppressor gene products for cell growth [136-139], or when either glycolysis or OxPhos is inhibited, in whose case there can be partial compensation by the other metabolic pathway [17]. Shifting the balance between those two processes with glycolytic and/or mitochondrial enzyme inhibitors might represent an interesting way to look for new anticancer agents.

The first step in the metabolism of glucose is catalyzed by the enzyme hexokinase $(\mathrm{HK})$ which by phosphorylating glucose makes it negative, sequestering it into the cytoplasm in the form of glucose-6-phosphate (G6P). In normal tissues, this crucial step is catalyzed by four different $\mathrm{HK}$ isoforms (HK1, HK2, HK3, and glucokinase) indicating that regulation of glucose phosphorylation can vary in different tissues under different condition [140]. HK1 and HK2 have overlapping tissue expression, but different subcellular distributions, with HK1 associated mainly with mitochondria and HK2 associated with both mitochondrial and cytoplasmic compartments [141]. HK1 is widely and constitutively expressed, whereas HK2 predominates during embryogenesis and is not widely expressed in adult tissues but only in a limited number of normal adult tissues [141]; their different subcellular distributions and kinetic properties reflect their different metabolic roles [141, 142]. Under physiological conditions, $\mathrm{HK} 1$ is predominantly bound to the outer mitochondrial membrane where it primarily channels glucose toward glycolysis [140], whereas HK2 is mainly soluble and controls glycogen formation [140, 141]. In malignant tissues, HK1 and HK2 isoforms are glycolytic and overexpressed (HK1 more than HK2) (http://www.proteinatlas.com/) [143] and are tightly bound to mitochondria. $\mathrm{HK} 1$ and $\mathrm{HK} 2$ bind through their N-terminal hydrophobic regions to the voltagedependent calcium channel isoforml (VDAC1), the prevalent pore protein in the outer mitochondrial membrane [24, 82, 143-146]. VDAC1 is also overexpressed in cancer cells [147], and the binding of HK to VDAC1 on the outer mitochondrial membrane is a fundamental aspect of the aerobic glycolytic metabolism of cancer cells [82, 135, 147, 148]. HK/VDAC association appears to protect tumor cells from mitochondrial outer membrane permeabilization (MOMP), which marks a point of no return leading to cell death [149]. VDAC transports ADP and inorganic phosphate $\left(\mathrm{P}_{\mathrm{i}}\right)$, the substrates needed for the production of ATP, into the mitochondria; it also transports ATP out of the mitochondria into the cytoplasm and facilitates the availability of ATP to HK2 [143, 150, 151]. A continuous supply of glucose to $\mathrm{HK}$ maintains this activity at a constant level and controls the flux through the mitochondrial electron transport chain, influencing mitochondrial ROS production [152]. HK binds through hydrophobic interaction to VDAC1, the prevalent pore protein in the outer mitochondrial membrane $[24,82$, 143-146], thereby assuring and gaining a preferential access to ATP $[82,150,153]$. Translocation of HK2 from the cytosol to the mitochondria is regulated through phosphorylation of HK by Akt [141]; HK2 only binds VDAC after phosphorylation by Akt $[151,152]$. Glycogen synthase kinase 3 beta (GSK3 $\beta$ ), a major target of Akt kinases, phosphorylates VDAC [154-157] and dissociates HK [156]. HK2 bound to mitochondria enhance its affinity to ATP and is less sensitive to enzymatic inhibition by the G6P product [140, $141,158]$. HK2 can produce G6P from cytoplasmic glucose and mitochondrial ATP without regulatory restraints, even under hypoxia, supporting rapid cell growth [142, 143, 159161]. $\mathrm{HK} 1$ and $\mathrm{HK} 2$ are more tightly bound to VDAC in cancer cells than in nonmalignant cells $[156,162,163]$. HK/VDA1 interaction is relatively stable for $\mathrm{HK} 1$, while it is dependent upon G6P levels for HK2 [140, 141]. The higher affinity of mitochondrial HK2 for glucose, ATP, and VDAC1 represents a high advantage for cancer cells survival and growth, conferring to them an aerobic glycolytic phenotype underlying the Warburg effect $[82,135,138,142,147,148,150,160]$. Differential interactions of $\mathrm{HK} 1$ and $\mathrm{HK} 2$ with mitochondria may underlie different glycolytic profiles in cancer cells [164, 165]. As rate-controlling enzymes in the glycolyic pathway, 
HKs represent important targets for anticancer therapies and drug development; HK inhibition induces cancer cells death and it is reportedly successful in the treatment of cancer [166-169]. In addition, the association between HKs and VDAC provides another therapeutic target. Peptides as well as small molecules that disrupt the interaction between $\mathrm{HK}$ and mitochondria can selectively kill tumor cells both in vitro and in vivo $[149,169]$.

One of the major findings concerning $\mathrm{MJ}$ is that it was able to detach HK1 and HK2 from VDAC in a timeand dose-dependent manner in the mitochondrial fraction of murine colon carcinoma CT-36 cells, human leukemic Molt- 4 and murine BCL1 cells, and murine B16 melanoma tumor cells by specifically binding to $\mathrm{HK} 2$, as judged by $\mathrm{HK}$ immunochemical, surface plasmon resonance and planar lipid bilayer VDAC-activity analyses, without inhibiting the kinase activity [30]. These authors emphasized that the susceptibility of cancer cells and mitochondria to jasmonates was dependent on HK overexpression and its association to mitochondria [30]. Dissociation of HK2 from VDAC changed mitochondrial membrane permeability, induced cytochrome $c$ release, inhibited ATP synthesis, blocked OxPhos, caused a drastic reduction of intracellular ATP levels, and stopped ATP-driven membrane pumps, causing an overall irreversible bioenergetic damage leading mitochondria to swell and burst and to cell death (Figure 2) $[17,20,30]$. The HK2/VDAC disruption event dissociated glycolysis from OxPhos and in glycolytic cells such as, for instance, CaSki cervical [26], and multiple myeloma [105] cells, and MJ treatment induced an increase in lactate production, whereas at the mitochondrial level, cell death by the intrinsic apoptotic and also by nonapoptotic pathways (including necrosis) was promoted [149], probably related to increased ROS levels [163] (Figure 2). On the other hand, MJ treatment induced an increase in phospho(p)-Akt levels in sarcoma cell lines and activation of the PI3K/Akt pathway attenuated the cytotoxic effect of MJ [49]. This effect was blocked by PI3K/Akt pathway inhibitors and by 2-deoxy-D-glucose (2DG) (Table 3) inducing sensitization toward MJ cytotoxicity in a synergistic manner [49].

MJ-induced ATP depletion was independent of pyruvate (an OxPhos substrate) and oligomycin (an OxPhos inhibitor) [17], but it was inhibited by glucose (a glycolysis substrate); nonetheless, 2-deoxy-D-glucose (a glycolysis inhibitor) synergistically enhanced the anticancer effect of MJ [170] (Table 3). The above described MJ-induced bioenergetic effects were observed only in mitochondria isolated from cancer cells, but not in those isolated from normal cells $[19,38,170]$, supporting the general idea that MJ interacts with molecular structures on the outer mitochondrial surface of cancer cells that may be exposed in a substantially different manner than in non-cancerous cells (for instance, the HK2/VDAC complex) [24, 30, 149, 163].

2.5. Jasmonates Stimulate the MAPK Stress Pathways and This Effect Leads to Differentiation in Some Cancer Cell Types and to Apoptosis in Others. MAPK pathways are critical for converting diverse extracellular stress signals (ROS, mitogens, mediators of inflammation, and other stressors) to biological responses, such as cell growth, survival, proliferation, inflammatory responses, apoptosis, and differentiation [171]. The main MAPK subfamilies of signaling pathways include the stress-regulated c-Jun $\mathrm{NH}_{2}$-terminal kinase (JNK), the p38MAPK, and the extracellular signal-regulated kinase-1/2 (ERK1/2) pathways. ERK1/2 behaves mainly as mitogenactivated proliferation/differentiation factors [172], whereas JNK and p38-MAPK pathways stimulates the AP-1 transcription factor and regulate responses for cell survival and inflammation and mediate cell death resulting from exposure to various stressors stimuli [173-175].

MJ was able to activate MAPK pathways in different cancer cells types (Table 1). (1) In acute human T-lymphoblastic Molt-4 leukemic cells, MJ activated JNK and p38-MAPK stress responses resulting in AP-1 activity; however, this signaling did not mediate the observed apoptotic leukemic cell death [18]. (2) In A549 lung carcinoma cells a similar effect was seen $[19,36]$. The effect of MJ in these two cases was independent of JNK and p38 activities, and AP-1 did not mediate the apoptosis effect on these cells and is independent of RNA and protein synthesis [18]. Thus, MJ induced two independent processes in Molt-4 leukemic cells: apoptotic death and a typical MAPK/JNK and p38 stress response [18]. (3) MJ also activated the p38-MAPK and ERK1.2 pathways in melanocytic MDA-MB-435 cells, but not in the human adenocarcinoma breast cell line MCF-7 $[25,74]$. (4) MJ activated the MAPK pathway in the human myelocytic leukemia cell line HL-60, but the outcome of this event was cell differentiation rather than apoptosis [41]; the differentiation effect was inhibited by PD98059, a MEK1 inhibitor, confirming the involvement of MAPK/ERK pathway in this MJ-mediate activity [41]. Acute myeloid leukemia (AML) is one of the worst forms of leukemia (AML blasts are immature myeloid cells), because it is largely resistant to chemotherapeutic drugs and other forms of therapy [176]. These cells can be induced to differentiate into normal, functional myeloid cells by different chemicals; unfortunately, many of these chemicals are too toxic to be used clinically (http://www.cancer.org/ acs/groups/cid/documents/webcontent/003110-pdf.pdf). MJ $(0.4 \mathrm{mM})$ stopped the growth of these blast cells and promoted their differentiation to normal cells, as deduced from the expression of markers of differentiation such as NBT reduction (for myelomonocytic differentiation), morphological differentiation into granulocytes, and expression of CD14 (monocyte-specific) and CD15 (granulocyte-specific) surface antigens [41]. MJ induced also the expression of the $\mathrm{Ca}^{2+}$ binding protein S100P in these cells, reported to be linked to induction of differentiation (Table 1) [42].

\subsection{Methyl Jasmonate and Some of Its Synthetic Derivatives} Showed Anti-Inflammatory, Antiangiogenic, and Antimetastatic Activities. The relationship between inflammation and cancer has been widely accepted; particularly, chronic inflammation is a key component where ROS is generated, creating a tumor microenvironment that promotes tumor progression [177]. Relevant inflammation targets in cancer include COX2, 5-lipoxygenase (5-LOX), and inflammation factors (e.g., inflammatory cytokines: TNF, IL-1, IL-6, and chemokines). 


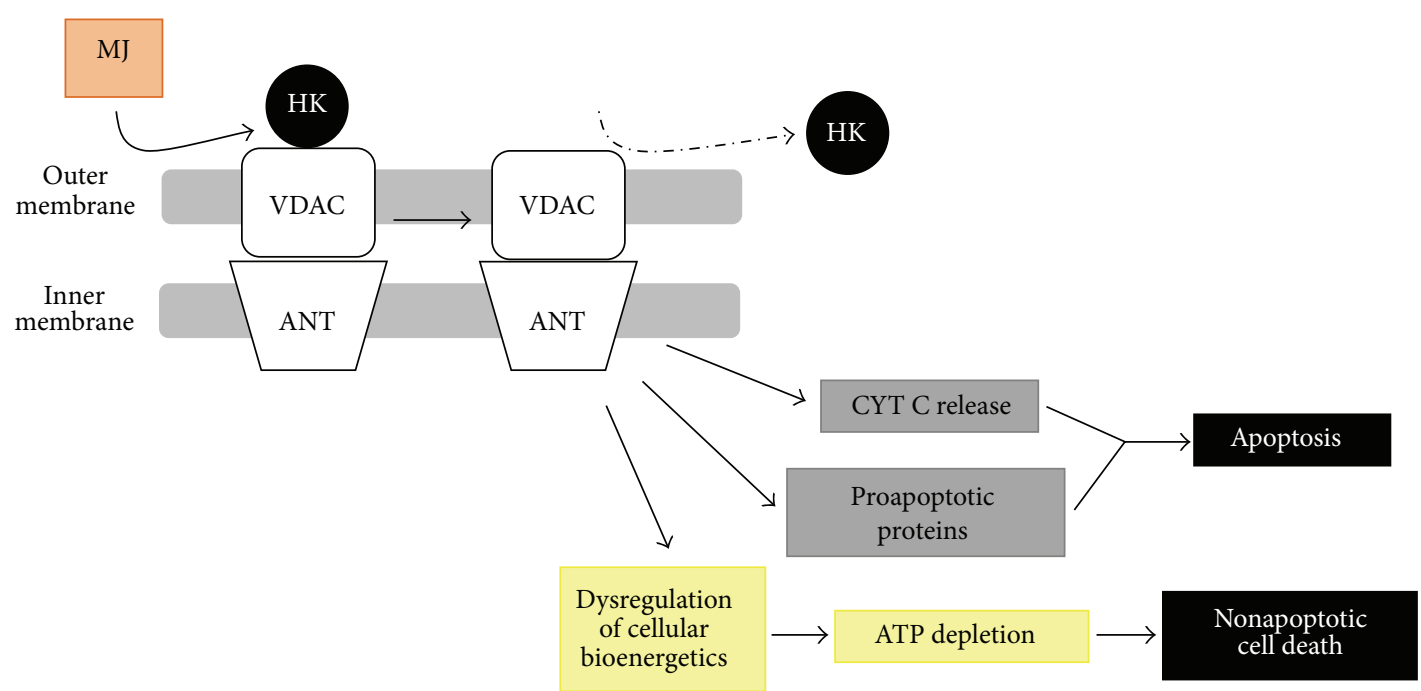

FIGURE 2: Effect of methyl jasmonate (MJ) on the mitochondrial bioenergetic metabolism of cancer cells. MJ dissociates HK2 from VDAC1 on the outer surface of mitochondria. As an immediate consequence, glycolysis dissociates from oxidative phosphorylation (OXPHOS) and a series of rapid events that occur, such the PTPC opening, mitochondrial membrane permeability deregulation and swelling, decrease of $\Delta \psi_{m}$ and OXPHOS, ATP depletion, cytochrome $c$ release, induction of proapoptotic proteins, and cell death through apoptotic and nonapoptotic pathways.

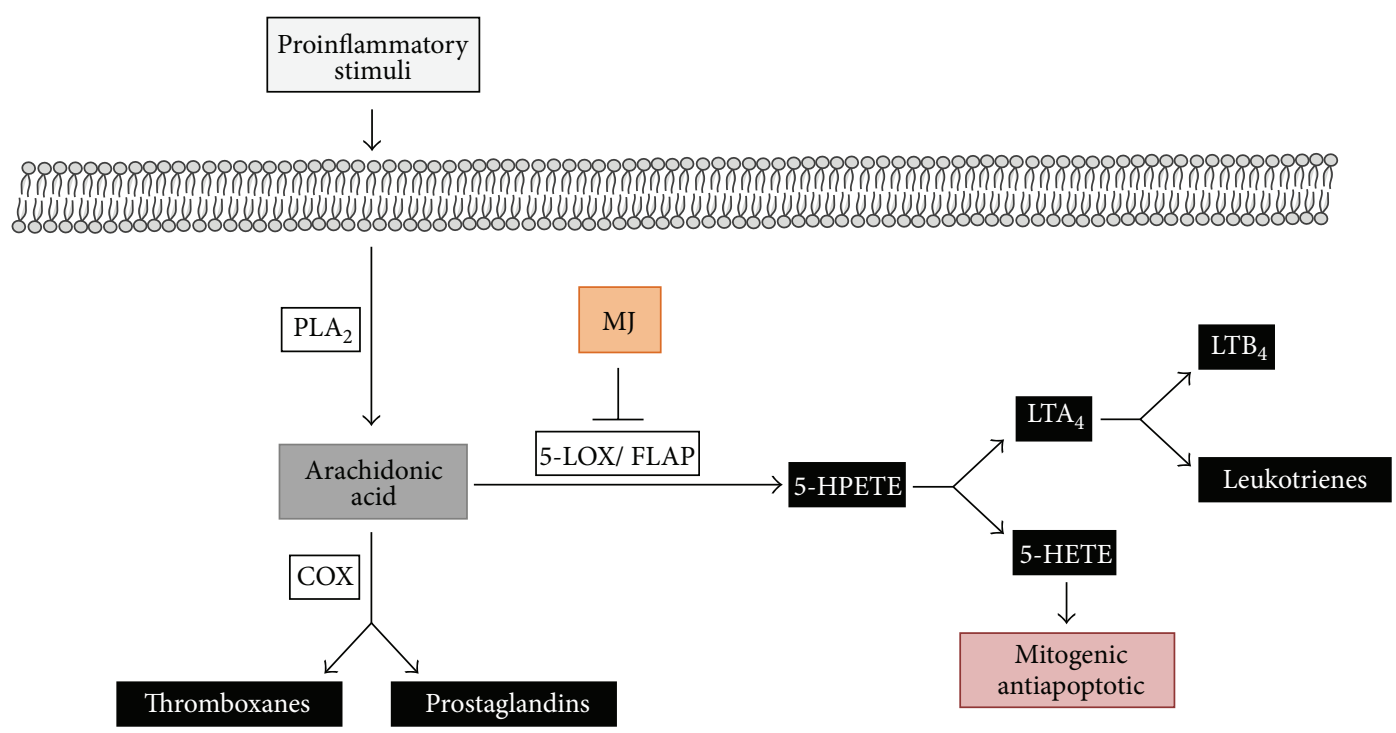

FIgURE 3: 5-Lipoxygenase (5-LOX) pathway in mammalian cells. Methyl jasmonate (MJ) can inhibit this pathway at the 5-LOX level in cancer cells [47]. The multiple consequences of this effect are (1) blocking 5-lipoxygenase-mediated ROS production (lipid hydroperoxides-LOOH); (2) antiproliferative effect linked to inhibition of 5-HETE production; (3) inhibition of leukotrienes production.

The synthetic MJ-derivatives methyl 4,5-didehydrojasmonate (MDDHJ, or J2) and methyl 5-chloro-4,5-didehydro jasmonate (J7), in addition to their antiproliferative and prodifferentiation activity (Table 1 ), showed a significant antiinflammatory activities by decreasing nitric oxide (NO), interleukin-6 (IL-6), and TNF- $\alpha$ in LPS-activated murine macrophage (RAW264.7) cells [178, 179]. These activities were mediated through the inhibition of the NF- $\kappa$ B pathway and downregulation of miR-155 [178, 179]. On the other hand, MJ may also fights inflammation by blocking the proinflammatory 5-LOX-pathway [47] (Figure 3); 5-LOX is the first enzyme in the 5-lipoxygenase metabolic pathway leading to the synthesis of 5-HETE and leukotrienes, which are harmful proinflammatory substances having direct influence on a number of inflammatory chronic disease processes, including allergic reactions [180], and cancer progression (5LOX is overexpressed in many aggressive types of cancer, as discussed in the 2.7 section).

The establishment of a tumor generates new blood vessel formation, mainly through hypoxia; angiogenesis plays then an important role in the evolution of both cancer and inflammatory diseases, and it is considered as a potential 
target for cancer therapy [181]. JAs inhibited angiogenesis at high doses, but the reverse was seen at lower doses in the chorioallantoic membrane (CAM) of chicken embryo [40]. At present, we have not found satisfactory explanations for these results.

Metastasis, rather than the primary tumor, is primarily responsible for anticancer treatment failure, poor quality of life, and death in cancer patients. Cancer metastasis is highly complex and multistep process in nature, involving extracellular matrix degradation, modified tumor cell adhesion, active tumor cell migration, altered tumor cell proliferation, and altered cancer cell survival and angiogenesis; modulation of these processes, particularly the epithelial-tomesenchymal transition (EMT), in which there is a profound change in transcriptional gene expression [57], enables the cells to escape the primary tumor microenvironment and spread locally/distally establishing a proliferative focus at a secondary site [182]. MJ showed antimetastatic activity on the murine model of highly metastasic and drug-resistant B16F10 melanoma cells [39]. At low concentrations, MJ was able to reduced cell motility of melanoma cells and suppressed the in vivo melanoma growth in the lung; also, the synthetic MJ derivative 5,7,9,10-tetrabromo jasmonate prevented cell adhesion and inhibited lung metastasis at a lower dose than MJ ( $\mathrm{IC}_{50} 0.04 \mathrm{mM}$ vs. $\mathrm{IC}_{50} 2.6 \mathrm{mM}$ ) (Tables 1 and 2) [24, 39]. In addition, subcytotoxic concentrations of MJ (0.05$0.2 \mathrm{mM}$ ) abolished migration, invasion, and angiogenesis of gastric cancer cells through downregulation of matrix metalloproteinase 14 (MMP-14) [33] (Table 1).

2.7. Methyl Jasmonate Can Inhibit the Phase I DrugMetabolizing Enzyme Aldo-Keto Reductase 1 (AKFR1) that Provides Drug-Resistance in some Tumor Cells. Aldo-keto reductases (AKRs) are soluble cytoplasmic $\mathrm{NAD}(\mathrm{P})(\mathrm{H})$ oxidoreductases that reduce aldehydes and ketones to yield primary and secondary alcohols, respectively [183]. Because this reaction permits subsequent conjugation reactions to occur (e.g., sulfation and glucuronidation), AKRs can be referred to as Phase I drug-metabolizing enzymes. The human AKRs can metabolize a vast range of substrates, including drugs, carcinogens, and reactive aldehydes leading to either their bioactivation or detoxification [183]. AKRs are generally monomeric $34-37 \mathrm{kDa}$ proteins present in all phyla; the superfamily consists of 15 families, which contains 151 members (http://www.med.upenn.edu/akr/). Thirteen human AKRs exist that use endogenous substrates (sugar and lipid aldehydes, prostaglandins [184], retinals, and steroid hormones), and in many instances they regulate nuclear receptor signaling [185]. Exogenous substrates include metabolites implicated in chemical carcinogenesis [183]. Human AKRs are highly polymorphic and there is interindividual variation affecting susceptibility to nuclear receptor signaling and chemical carcinogenesis [185]. AKR 1 member B1 (AKR1B1) and AKR 1 member B10 (AKR1B10) are overexpressed in human tumors, such as liver, breast, and lung cancer, and may play critical roles in the development and progression of cancer through carbonyl detoxification, retinoic acid homeostatic regulation, and lipid metabolic control, as well as the activation of tobacco smoke carcinogens [186]. Members of the AKRF1 family are being consistently identified as potential biomarkers for various types of cancer cells [187-189]. Increased mRNA expression of AKR1B1, AKR1C2, and carbonyl reductase (CR) and induction of carbonyl-reducing enzymes AKR1B1 and AKR1C2 can account for drug resistance to some anticancer agents [190-192], for instance, the resistance of human stomach carcinoma cells to daunorubicin [193]. AKR1B1 was also linked to doxorubicin and cisplatin resistance in HeLa cervical carcinoma cells because an AKR1B1 inhibitor enhanced the cytotoxic effects of these anticancer agents [194]. All this information clearly indicates that members of the AKR superfamily are emerging as important mediators of cancer pathology $[132,192]$ and as new targets in cancer drug resistance; therefore AKR1 inhibitors may represent a novel class of antitumor agents.

MJ can bind to members of the AKRF1 family [132] and a correlation has been identified between cell sensitivity to $\mathrm{MJ}$ and lower intracellular protein levels of HK2, pVDAC2/3, and AKR1C1 [105].

\subsection{Many Aggressive Cancer Cell Types Overexpress 5-} Lipoxygenase (5-LOX) to Produce the Highly ProliferationStimulating Metabolite 5-HETE; MJ Can Inhibit 5-LOX. Lipoxygenases (LOX; linoleate: oxygen oxidoreductase) are a family of monomeric nonheme, nonsulfur iron dioxygenases that catalyze the oxidation of polyunsaturated fatty acids (PUFAs) having a cis, cis-1,4-pentadiene moiety into lipid hydroperoxides [195]. LOX isozymes add a hydroperoxide group $\left[{ }^{-} \mathrm{OOH}\right]$ at carbons 5,12 , or 15 of $\mathrm{AA}$ and are designated 5-, 12-, or 15-lipoxygenases [196]. The major substrates for lipoxygenases in higher plants are linoleic acid $(18: 2)$ and linolenic acid $(18: 3)$. In animals, LOXs catalyse the oxygenation of arachidonic (AA) (eicosatetraenoic, C20:4; ETE) acid released from membrane phospholipids by phospholipase A [197] and LOX-derived metabolites participate as signals in several biochemical and physiological processes (http://en.wikipedia.org/wiki/Arachidonic_acid). Arachidonic acid (AA) can be also converted by cyclooxygenase (COX) to prostaglandins (PGs) and other metabolites. LOX converts AA into 5-hydroperoxy-eicosatetranoate (5-HPETE) and then into 5-hydroxy-eicosatetranoic acid (5-HETE) and leukotrienes (B4) (Figure 3). The AA-metabolites derived from COX or LOX reactions modulate many cellular processes and participate not only in various inflammatory reactions, but also in proliferation and apoptosis [195]. Our bodies respond to high levels of dietary-generated AA (triggered by foods rich in $\omega-6$ fatty acids and high-glycemic carbohydrates) by increasing the expression of 5-LOX [198]. 5-Lipoxygenase pathway metabolites 5-hydroxy-6,8,11,14-eicosatetraenoic acid (5-HETE) and leukotriene LTB4 stimulates growth and increases survival of cancer cells overexpressing 5-LOX [199-203]. 5-HETE, which enhances cell proliferation and activates also antiapoptotic signaling (Figure 3), has been implicated in human cancer progression. 5-HETE strongly stimulates the growth of hormone-responsive (LNCaP) 
and hormone-refractory (PC-3) human prostate cancer cells [204, 205]. 5-LOX is rate limiting for the synthesis of 5-HETE and subsequent LTs production; thus, inhibition of 5-LOX would inhibit the generation of these proinflammatory metabolites while promoting cell death [47, 206-211].

Overexpression of 5-LOX has been shown in tissue samples of primary tumor cells [212], in established cancer cell lines and most human aggressive cancers such as breast MDA-MB-231 cells [208], PC-3 prostate cells [47, 204, 205, $207,213]$, bladder [15, 214], esophagus [211, 215], pancreas [216], gastric [217], and malignant pleural mesothelial cells [218], as well as lung [219], brain [15, 220], colon [221], hepatocellular carcinoma (HCC) [222], neuroblastoma [223], colorectal [224], glioma cells [225], and Barret's adenocarcinoma [226]; 5-LOX overexpression has been also found in oral carcinoma [227] and canine osteosarcoma [228], all examples strongly suggesting the involvement of 5-LOX in cancer progression. Targeting 5-LOX with specific inhibitors or inhibiting its interaction with the 5-LOX-activating protein (FLAP) has resulted in decreased cell growth and increased apoptosis in lung and breast cancer cell lines [201, 229]. The pharmacological inhibition of 5-LOX by the specific synthetic inhibitor MK886 blocked 5-HETE production potently suppressed tumor cell growth, induced cell cycle arrest, and triggered cell death via the intrinsic apoptotic pathway [204, 230, 231]. Inhibition of 5-LOX activity induced apoptosis in human prostate cancer cells [232] and human pancreatic cancer cells [230] and xenographs [200]. Both the inhibition of 5-LOX activity and the induction of apoptosis in prostate cancer cells were reversed by the addition of 5-HETE [204, 233, 234].

LOX isozymes can be activated and upregulated by UV light exposure, bad fat diets, oxidative stress, ligand-receptor activation (drugs, Fas), ROS-inducing medications, lipid hydroperoxides (LOOH) [198], and their secondary ROS derivatives (free radicals, hydroxides, ketones, aldehydes, etc.) that can exert deleterious effects on membrane lipids (including mitochondrial membrane lipids), thus conforming the first critical step in oxidative stress leading to cell death by the LOX-pathways. Mitochondria that have been damaged by lipid peroxidation decrease their membrane potential $\left(\Delta \psi_{m}\right)$, increasing cytochrome $c$ release, and caspase activation, all these events ultimately leading to apoptosis [195, 235]. LOX-mediated apoptosis implies the following: (1) ROS that (hydroperoxides) induced modifications of membrane properties (exposure of phosphatidylserine, increased levels of cholesterol, and consequently altered Ras expression); (2) modifications of cytoskeleton; and (3) modifications in gene transcription (through nuclear factor NF$\kappa \mathrm{B}$, poly(ADPribose) polymerase [195]). Apoptosis triggered after an oxidative stress caused by lipoxygenase activation is a common signal transduction pathway shared by animal and plant cells that has been conserved through evolution [235]. The most interesting is the fact that MAPK/ERK, p38MAPK, and MAPK/MEK stress pathways stimulate 5LOX by phosphorylation [236-238]. 5-LOX phosphorylation does not affect the enzyme catalytic activity but rather regulates its interaction with other cellular components [239, 240]. Thus, for instance, p38 MAPK can phosphorylate
5-LOX at Ser271; phosphorylation at this site is responsible for the stress-induced nuclear export of 5-LOX in CHO-K1 cells (a cell line from Chinese hamster ovary) and HEK293 (human embryonic kidney 293) cells [237], whereas in NIH 3T3 (mouse embryonic fibroblastic) cells, phosphorylation at Ser271 stimulates nuclear localization and subsequently, cellular 5-LOX activity [236].

5-LOX is an important target of JAs since these oxylipids are synthesized in plants via 12-oxo-phytodienoic acid (12oxo-PDA) - product of an oxidative cyclization of $\alpha$-linolenic acid resulting in cyclopentanones $[3,4]$. There are structural and biogenic similarities of 12-oxo-PDA and jasmonates to animal prostanglandins $[3,15,38]$. It is not then a surprise to find that JAs can inhibit the lipoxygenase pathway in animals, MJ being itself a secondary cyclopentanone product derived from of $\alpha$-linolenic acid. MJ significantly inhibited proliferation and induced apoptosis and necrosis in extremely malignant human prostate cancer cells within hours, in dose- and kinetic-dependent manners, showing specific interaction with the 5-LOX pathway [47] (Table 1, Figure 3). The mechanism of inhibition of 5-LOX activity by MJ is still unknown; it is not known if JAs are able to directly interact with the catalytic site of 5-LOX or cause indirect inhibitory effects through interaction with an allosteric site or its regulatory 5-lipoxygenase-activating (FLAP) protein. Relevant to this point is the fact that 5-LOX inhibition may cause cytotoxic and antiproliferative effects in cancer cells independently of suppression of the 5-LOX catalytic activity [239].

\section{Therapeutic Advantages of Combining Jasmonates with Conventional Anticancer Drug Treatments}

Conventional anticancer treatments (surgery, radiation, chemotherapy, and targeted therapies) are all strong inducers of ROS and, as discussed before, ROS excess is a major mechanism for inducing cell death through apoptosis [58, 241]. Excess ROS is highly proinflammatory to cancer neighboring normal cells tissues, being mostly responsible for the painful and aggressive side effects observed in cancer patients [242]. Many phytochemicals have been shown to have anti-inflammatory and also cancer-preventing and anticancer properties (linked to metabolism, proliferation, invasion, angiogenesis, and metastasis activities) showing in addition relatively low toxicity to normal cells [243]. Thus, a rational for a good clinical strategy is combining harsh anticancer treatments with natural anti-inflammatory and cancer-preventing compounds to increase treatment efficacy while lowering drug dose and toxicity [244-246]. However, combination of components having opposite effects, such as for instance antioxidants (anti-ROS), may impair treatment efficacy [57]. Additive and synergic effects may actually be quite advantageous reducing the side effects often seen with single high drug doses treatments in addition to preventing resistant tumor cells to develop [245-247]. Considerable amount of research has been done to identify the relevant molecules that contribute to drug efflux and drug resistance, 


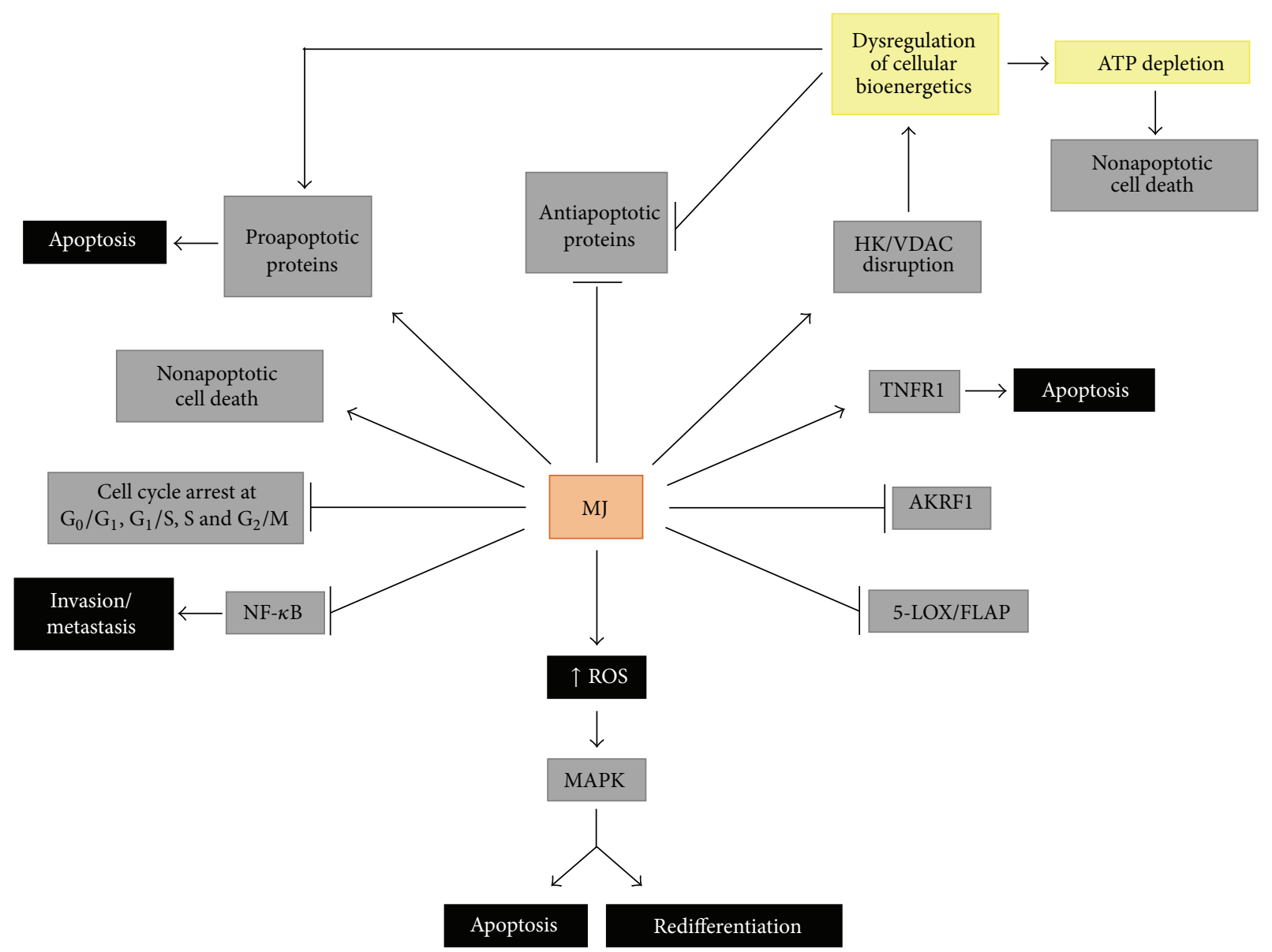

FIGURE 4: Methyl jasmonate mediated activities in cancer cells. MJ and other jasmonates (JAs) (1) arrest cell cycle, inhibiting cell growth and proliferation; (2) cause cell death by triggering the intrinsic and extrinsic proapoptotic pathways and induce also p53-independent apoptosis and nonapoptotic cell death or necrosis; (3) detach hexokinase (HK) from the voltage-dependent anion channel isoform 1 (VDAC1), dissociating glycolytic and mitochondrial functions, decreasing the mitochondrial membrane potential $\left(\Delta \psi_{m}\right)$, favoring cytochrome $c$ release, causing ATP depletion, and activating proapoptotic and inactivating antiapoptotic proteins; (4) induce reactive oxygen species (ROS), triggering and/or mediating different cellular responses; (5) stimulate MAPK-stress signaling pathways and induce redifferentiation in leukemia cells; (6) inhibit overexpressed cancer cell enzymes such as aldo-keto reductase 1 (AKR1) and 5-lipoxygenase (5-LOX).

but the interdependence and cross-talk between metabolic pathways grant cancer cells a high metabolic plasticity, favoring their adaptation to new environmental and stressful conditions $[245,248]$. For these reasons, phytochemicals, by being pleiotropic and multitarget, have the great ability to concomitantly modulate multiple metabolic and survival pathways, becoming selectively cytotoxic to cancer cells without inducing toxicity in normal cells [243]; through these properties, phytochemicals can regulate the death receptor pathways and overcome multidrug resistance (MDR) proteins, as documented by multiple examples in laboratory and clinical practice [248].

By the way of its multiple and different mechanisms of action (Figure 4), MJ may display strong cooperative efficacy with other anticancer agents to induce death in several cancer cells, helping also to overcome multidrug resistance $[19,23,170]$. Combination of MJ with any anticancer drug may have a different rational, synergism being the first and the more important one to take into consideration.
If synergism is present, combined MJ-drug formulations may allow for less toxic drug concentrations while keeping an efficient treatment. Chemical structure, physicochemical properties, and molecular mechanisms of action of selected drugs are also important parameters to be considered for combination. MJ is a small molecular weight fatty acidderived cyclopentanone which is very hydrophobic and is not charged; it would act then better on membranes, and amphipathic vehicles should be considered if combined with hydrophilic drugs. JAs, MJ, and their derivatives have been combined with ionizing radiation, conventional chemotherapy drugs, and also with other phytochemicals, to enhance cancer cell cytotoxicity in anticancer treatments, allowing for lower effective doses while showing enhanced efficacy in inducing death of carcinoma cells (Table 3 ) $[23,28,170]$. MJ is very selective for cancer cells [17], it is not toxic for normal cells $[15,50]$, and it induces cell death primarily by triggering mitochondrial perturbation (detachment of HK from the outer mitochondria membrane [30], prooxidant activity, 
etc.) as deduced from previous discussion. Most aggressive cancers show a glycolytic metabolic profile, and combination of glycolysis inhibitors with OxPhos inhibitors enhances the anticancer properties of this combination. Thus, combination of MJ with 2-deoxy-D-glucose (glycolysis inhibitor) and with four conventional chemotherapeutic drugs resulted in super-additive cytotoxic effects on several types of cancer cells (Table 3). MJ is clearly a mitochondriotoxic anticancer compound, and compounds that directly target mitochondria offer the advantage to induce mitochondrial outer membrane permeabilization independently of upstream signal transduction elements that are frequently impaired in human cancers; in this way, mitochondrion-targeted agents may bypass some forms of drug resistance [96] and cause nonapoptotic cell death.

From Tables 1 and 2 we can infer that MJ acts on a wide gamma of cancer types in vitro and in vivo, and this property is probably due to its capacity to target multiple metabolic pathways in different cancer cell types, leading to apoptotic and nonapoptotic cell death, as already discussed above. The reported cooperative effects of $\mathrm{MJ}$ with other drugs are shown in Table 3: (1) BCNU (carmustine), an alkylating nitrosourea agent with no cytotoxic effect on pancreatic carcinoma cell line MIA $\mathrm{PaCa}-2$ in vitro combined with $\mathrm{MJ}$ showed enhanced cell death [170]. The underlying molecular mechanisms in this combination are probably related to the DNA damaging action of BCNU on mitochondria [249] rendering the above cells sensitive to $\mathrm{MJ}$ which also alter the mitochondrial function [32], thus showing a highly additive cytotoxic effect of two combined mitochondriotoxic agents. This combination acted also synergistically on murine B-cell leukemia (BCL1) cells [170]. (2) MJ (a mitochondriotoxic compound) combined with 2-deoxy-D-glucose (2DG) (an inhibitor of glycolysis) showed synergic/additive effects and cell death on various carcinoma cell types (Table 3) [170]; the synergic effect was probably due to OxPhos/ATP biosynthesis inhibition by MJ and to glycolytic/ATP biosynthesis inhibition by 2DG [17]. MJ enhanced also the toxic effects of taxol [170] much by the same reasons discussed in (1); taxol induces mitochondrial membrane depolarization resulting in translocation of apoptosis-inducing factor (AIF), but not cytochrome $c$, from the mitochondria to the cytosol. (3) MJ enhanced significantly the in vivo antileukemic toxic effect of the antibiotic adriamycin (doxorubicin) in a chronic lymphocyte leukemia (CLL) mouse model [170]; adriamycin increases the intracellular levels of ROS, followed by mitochondrial membrane depolarization, cytochrome $c$ release, and caspase 3 activation; the $\mathrm{IC}_{50}$ value for adriamycin dropped by half when combined with MJ [170, 250]. (4) MJ treatment increased the levels of pAkt in sarcoma cell lines MCA-105 and SaOS-2; however, the treatment of both cell lines with a combination of MJ and small molecular weight PI3K/Akt inhibitors resulted in a synergistic cytotoxic effect [49]. (5) Glucose attenuated the MJ-induced cytotoxicity in these cells; but the treatment with a combination of MJ plus 2DG resulted in a synergistic cytotoxic effect [49]. (6) MJ suppressed the $\gamma$-radiation-induced expression of Bcl2 in human prostate cancer cells enhancing the sensitivity of these cells to $\gamma$-radiation [104]. (7) MJ combined with the monoterpene perillyl alcohol $(\mathrm{POH})$ enhanced the cytotoxicity of cisplatin in breast MDA-MB-231 cells and in MDAMB-435 cancer cells [74, 251]. MJ and POH activate TNFR1 (extrinsic apoptosis pathway), which is further increased by the addition of cisplatin [251]. MJ and $\mathrm{POH}$ decrease mitochondrial membrane potential (intrinsic apoptosis pathways) inducing cytochrome $c$ release, and this effect is further enhanced by cisplatin whose cytotoxic activity seems to be largely dependent on the glycolytic metabolism of tumor cells (cisplatin would redirect cancer cells to oxidative phosphorylation from the "Warburg effect") [252]; in this example, the three drugs treatment was more effective than single drug or two drugs together [251]. (8) Survivin (an inhibitor of apoptosis protein (IAP) member) negatively regulates TRAIL-mediated apoptosis in colorectal cancer (CRC) cells but MJ, by downregulating the Wnt/transcription factor pathway, prevented the overexpression of survivin thus sensitizing cancer cells for TRAIL-mediated cytotoxicity [32]. TRAIL is also able to induce apoptosis in prostate cancer cells; however, overexpression of antiapoptotic proteins and inhibition of proapoptotic proteins results in lowering the TRAIL-mediated apoptosis [253]. (9) MJ combined with the Smac peptide (inhibitor of IAPs) showed IAPs-inhibiting synergy in human bladder EJ and T24 cells and human embryonic kidney HEK 293 cells [254]. (10) Hormonerefractory prostate cancer cells are relatively resistant to $\mathrm{MJ}$ because the overexpression of IAP proteins decreases the proapoptotic activity of MJ. In these cases, the IAP antagonist SmacN7 (a synthetic peptide comprising the first N-terminal seven residues of Smac) was successfully used to synergically potentiate MJ-mediated apoptosis [255]. The SmacN7/MJ combination induced sensitization to apoptosis through both caspase-9-dependent and caspase-9-independent pathways [255]. (11) MJ worked synergically with cisplatin as well as with X-rays irradiation on various cervical cancer cell lines enhancing the cytotoxic effects of these conventional therapies, lowering the effective doses required to inhibit survival of those cells [29]. MJ worked also well with $\alpha$-irradiation enhancing the selective reduction of cell viability and survival of cervical cancer cells effected by $\alpha$-rays [29]. (12) MJ combined with 5-FU in human adenocarcinoma colon HT39 cells drastically decreased the 5 -FU IC $_{50}$ values, which is important to reduce the unwanted side effects usually associated with this drug [31]. (13) MJ synergized also with bortezomib (a proteasome inhibitor) in vitro and prolonged survival of immunocompromised mice harboring diffuse lesions of multiple myeloma (MM.1S) cells as compared to vehicle-treated mice [105].

\section{Concluding Remarks and Hypothesis}

As inferred from the many in vitro and in vivo evidences discussed here, JAs are highly selective towards malignant cells (excepting hormone-independent prostate cancer cells and some sarcoma cell lines which are relatively more resistant to $\mathrm{MJ}$ than other cancer cells), not affecting normal cells. Of particular interest is to know that MJ is well tolerated, and no meaningful local or systemic side effects have been 
detected in animal and humans trials after toxicology and dermatology studies for acute toxicity, skin irritation, mucous membrane (eye) irritation, skin sensitization, phototoxicity, and photoallergy, not being toxic to healthy organisms of different species so far tested and emphasizing the safety of MJ use in humans [50-52]. JAs and particularly MJ have been shown to stimulate and/or to inhibit multiple intracellular pathways and proteins (Figure 4) that may be differently expressed among different cancer cell types. MJ anticancer activities can be summarized as follows: (1) MJ is able to induce reactive oxygen species (ROS), that are subsequent mediators of different intracellular responses; (2) ROS may stimulate the MAPK-stress signaling pathways, inducing ERK-dependent redifferentiation, or apoptosis in leukemia cells; (3) MJ induces cell cycle arrest at different phases in different types of cancer cells, interfering by this way cell growth, proliferation, and migration; (4) MJ promoted the detachment of hexokinase (HK) from to the voltagedependent-anion-channel isoform 1 (VDAC1) in the outer mitochondrial membrane, dissociating glycolytic and mitochondrial metabolic functions; this event decreases the mitochondrial membrane potential $\left(\Delta \psi_{m}\right)$, favoring cytochrome $c$ release, causing ATP depletion, activating proapoptotic, and inactivating antiapoptotic proteins; (5) MJ induces cell death by triggering the intrinsic/extrinsic proapoptotic, and also nonapoptotic pathways; (6) MJ inhibits metabolic enzymes such as the aldo-keto reductase 1 (AKR1) and 5-lipoxygenase (5-LOX) that favor cancer cells survival and proliferation and that have been found overexpressed in aggressive cancer cells; (7) Jasmonate-mediated anti-inflammatory activities involving downregulation of $\mathrm{NF}-\kappa \mathrm{B}$ transcription factor activity $[178,179]$ and inhibition of the 5-LOX pathway; (8) MJ and some of synthetic derivatives inhibit cancer cell invasion and metastasis through downregulation of the $\mathrm{NF}-\kappa \mathrm{B}$ transcription factor and miR-155 [178, 179]. These pathways may all or partially be expressed in a given cancer cell type at agiven time, and MJ (JAs) can target all of them, causing a catastrophic cancer cellular failure and subsequent cell death (except when inducing redifferentiation), while sparing normal cells. As stated by Elia and Flescher [23], all MJ anticancer mechanisms are not mutually exclusive and may occur concomitantly, so affecting different cancer cells, or can be active in different time frames and concentration ranges [23]. Thus, MJ can probably act simultaneously on all the above targets within the same cell population, and cells may then die by apoptotic and/or nonapoptotic mechanisms, as it was observed by Kniazhanski et al. [26] and Milrot et al. [28] on cervical cancer cells after treatment with MJ (Table 1).

Integrating all the above knowledge we might hypothesize the jasmonates (mainly MJ) mechanisms of action leading to death mammalian cancer cells. By its highly hydrophobic ciclopentanone lipid structure, MJ may easily get across cellular membranes; during this transit, the prooxidant nature of the MJ oxylipin causes an oxidative event that perturbs the lipid bilayer, as reflected by a decrease in membrane fluidity upon contact [25]; this event stimulates $\mathrm{NAD}(\mathrm{P}) \mathrm{H}$ oxidases (NOX) and generates reactive oxygen species (ROS) (mainly $\mathrm{H}_{2} \mathrm{O}_{2}$ ) [24], both events linked to functions in the MAPK stress pathways [25]; ROS may subsequently act as mediators of other cellular responses as well. The interaction of MJ with the surface plasma membrane might also be responsible for the increased expression of TNFR1 expression and caspase- 8 activation observed by Yeruva et al. [25] in some cancer cell types, activating this way the extrinsic pathway of apoptosis. Intracellularly, MJ may bind to lipids and hydrophobic proteins and also interact with subcellular organelles (mitochondria, nucleus, and peroxisomes). A possible mechanism(s) of surface structures discrimination between normal and cancer cells mitochondria by MJ seems to occur, and it is probably related to the overexpression and tight binding of hexokinase(s) $(\mathrm{HK})$ to the VDAC1 pore in the outer mitochondrial membranes (OMM) in cancer cells $[24,30]$. By binding to a hydrophobic $\mathrm{HK}$ region in the HK/VDAC1 complex on the OMM, MJ induces HK detachment from its VDAC anchor (Figure 2). When this happen, the $\mathrm{Bax} / \mathrm{Bcl}-2$ balance is altered, antiapoptotic $\mathrm{Bcl}$ 2 proteins are released from the OMM, and proapoptotic proteins occupy their sites inducing the intrinsic way of apoptosis; concomitantly, the mitochondrial membrane potential $\left(\Delta \psi_{m}\right)$ decreases, cytochrome $c$ is released, caspase-3 is activated, mitochondrial ATP depleted, ROS generated, and cell cycle arrested $[23,25,30]$, causing a catastrophic energy breakdown and cell death. Nonapoptotic cell death could be the consequence of the severe bioenergetic damages induced by the direct interaction of MJ with mitochondria, leading to increased ROS levels, inhibition of ATP synthesis, and ATP depletion $[20,30]$. However, depending on cancer cell type sensitivity to MJ, the extent of mitochondrial damage could be determinant for apoptotic and/or nonapoptotic cell death. In the nucleus, $\mathrm{MJ}$ may interact with cell cycle regulatory proteins (cyclins, CDKs, and survivin) inducing cell cycle arrest at different phases in different cancer cell types (Table 1), thus inhibiting cell cancer growth, proliferation, and invasion. MJ-induced downregulation of survivin severely affects cell cycle progression and induces apoptosis [32]. MJ induces TRAIL cytotoxicity, but overexpression of survivin prevents this activity [32]. When targeting several cellular processes, MJ induces ROS production; ROS influences cell cycle progression via phosphorylation and ubiquitination of CDKs and other cell cycle regulatory molecules [57].

The inhibition of multiple cancer cell activities by Jasmonates (MJ) becomes important when we think at cancer as a multifactorial disease that should be better treated through multitarget strategies. Due to their multitarget and pleotropic properties, JAs and particularly MJ are capable of rapidly killing many cancer cell types independently of factors such as cellular mRNA transcription, protein translation [18], and p53 expression [17] leaving untouched normal cells [15]. Due to these properties, MJ may act also as a chemosensitizer to chemotherapics and help to overcome drug-resistance [17, 19]; as seen in Table 3, MJ significantly reduced the $\mathrm{IC}_{50}$ values of chemotherapeutic agents with which it was combined. As it has been commented in this and other reviews, JAs can be used alone or in synergic combination with other anticancer drugs and might be seriously considered to be included safely in some of the current anticancer therapies. Finally, the rapidity by which $\mathrm{MJ}$ causes damage to cancer cells turns it into a promising anticancer agent of high therapeutic value. 


\section{Conflict of Interests}

The authors declare that there is no conflict of interests regarding the publication of this paper.

\section{Acknowledgments}

The research in our laboratory is financed by CNPq, FAF, and FAPERJ.

\section{References}

[1] A. Ertel, A. Verghese, S. W. Byers, M. Ochs, and A. Tozeren, "Pathway-specific differences between tumor cell lines and normal and tumor tissue cells," Molecular Cancer, vol. 5, article $55,2006$.

[2] X. Mou, S. Kesari, P. Y. Wen, and X. Huang, "Crude drugs as anticancer agents," International Journal of Clinical and Experimental Medicine, vol. 4, no. 1, pp. 17-25, 2011.

[3] R. Liechti and E. E. Farmer, “The Jasmonate pathway," Science, vol. 296, no. 5573, pp. 1649-1650, 2002.

[4] H. Weber, "Fatty acid-derived signals in plants," Trends in Plant Science, vol. 7, no. 5, pp. 217-224, 2002.

[5] W. W. Christie, "Plant oxylipins: chemistry and biology," 2010, http://lipidlibrary.aocs.org/lipids/eicplant/index.htm.

[6] G. Sembdner and B. Parthier, "The biochemistry and the physiological and molecular actions of jasmonates," Annual Review of Plant Physiology and Plant Molecular Biology, vol. 44, no. 1, pp. 569-589, 1993.

[7] N. I. Vasyukova, S. V. Zinovieva, Z. V. Udalova, N. G. Gerasimova, O. L. Ozeretskovskaya, and M. D. Sonin, "Jasmonic acid and tomato resistance to the root-knot nematode Meloidogyne incognita," Doklady Biological Sciences, vol. 428, pp. 448-450, 2009.

[8] E. E. Farmer and C. A. Ryan, "Interplant communication: airborne methyl jasmonate induces synthesis of proteinase inhibitors in plant leaves," Proceedings of the National Academy of Sciences of the United States of America, vol. 87, no. 19, pp. 7713-7716, 1990.

[9] M. De Vos, V. R. Van Oosten, R. M. P. Van Poecke et al., "Signal signature and transcriptome changes of Arabidopsis during pathogen and insect attack," Molecular Plant-Microbe Interactions, vol. 18, no. 9, pp. 923-937, 2005.

[10] M. M. Izaguirre, C. A. Mazza, A. Svatoš, I. T. Baldwin, and C. L. Ballaré, "Solar ultraviolet-B radiation and insect herbivory trigger partially overlapping phenolic responses in Nicotiana attenuata and Nicotiana longiflora," Annals of Botany, vol. 99, no. 1, pp. 103-109, 2007.

[11] R. Karban, "Plant behaviour and communication," Ecology Letters, vol. 11, no. 7, pp. 727-739, 2008.

[12] A. M. D. S. Soares, T. F. de Souza, T. Jacinto, and O. L. T. Machado, "Effect of methyl jasmonate on antioxidative enzyme activities and on the contents of ROS and $\mathrm{H}_{2} \mathrm{O}_{2}$ in Ricinus communis leaves," Brazilian Journal of Plant Physiology, vol. 22, no. 3, pp. 151-158, 2010.

[13] S. A.-H.-Mackerness, S. L. Surplus, P. Blake et al., "Ultraviolet$\mathrm{B}$-induced stress and changes in gene expression in Arabidopsis thaliana: role of signalling pathways controlled by jasmonic acid, ethylene and reactive oxygen species," Plant, Cell \& Environment, vol. 22, no. 11, pp. 1413-1423, 1999.
[14] L. Zhang and D. Xing, "Methyl jasmonate induces production of reactive oxygen species and alterations in mitochondrial dynamics that precede photosynthetic dysfunction and subsequent cell death," Plant and Cell Physiology, vol. 49, no. 7, pp. 1092-1111, 2008.

[15] O. Fingrut and E. Flescher, "Plant stress hormones suppress the proliferation and induce apoptosis in human cancer cells," Leukemia, vol. 16, no. 4, pp. 608-616, 2002.

[16] E. Flescher, "Jasmonates-a new family of anti-cancer agents," Anti-Cancer Drugs, vol. 16, no. 9, pp. 911-916, 2005.

[17] O. Fingrut, D. Reischer, R. Rotem et al., "Jasmonates induce nonapoptotic death in high-resistance mutant p53-expressing B-lymphoma cells," British Journal of Pharmacology, vol. 146, no. 6, pp. 800-808, 2005.

[18] R. Rotem, O. Fingrut, J. Moskovitz, and E. Flescher, "The anticancer plant stress-protein methyl jasmonate induces activation of stress-regulated c-Jun $\mathrm{N}$-terminal kinase and $\mathrm{p} 38$ protein kinase in human lymphoid cells," Leukemia, vol. 17, no. 11, pp. 2230-2234, 2003.

[19] E. Flescher, “Jasmonates in cancer therapy," Cancer Letters, vol. 245, no. 1-2, pp. 1-10, 2007.

[20] N. Goldin, A. Heyfets, D. Reischer, and E. Flescher, "Mitochondria-mediated ATP depletion by anti-cancer agents of the jasmonate family," Journal of Bioenergetics and Biomembranes, vol. 39, no. 1, pp. 51-57, 2007.

[21] S. Cohen and E. Flescher, "Methyl jasmonate: a plant stress hormone as an anti-cancer drug," Phytochemistry, vol. 70, no. 13-14, pp. 1600-1609, 2009.

[22] D. Reischer-Pelech and E. Flescher, "Jasmonates: plant stress hormones as anticancer agents," in Emerging Trends in Dietary Components for Preventing and Combating Disease, pp. 303-322, 2012.

[23] U. Elia and E. Flescher, "Combined chemotherapy or biotherapy with jasmonates: targeting energy metabolism for cancer treatment," Current Pharmaceutical Biotechnology, vol. 14, no. 3, pp. 331-341, 2013.

[24] Z. Raviv, S. Cohen, and D. Reischer-Pelech, "The anti-cancer activities of jasmonates," Cancer Chemotherapy and Pharmacology, vol. 71, no. 2, pp. 275-285, 2013.

[25] L. Yeruva, J. A. Elegbede, and S. W. Carper, "Methyl jasmonate decreases membrane fluidity and induces apoptosis through tumor necrosis factor receptor 1 in breast cancer cells," AntiCancer Drugs, vol. 19, no. 8, pp. 766-776, 2008.

[26] T. Kniazhanski, A. Jackman, A. Heyfets, P. Gonen, E. Flescher, and L. Sherman, "Methyl jasmonate induces cell death with mixed characteristics of apoptosis and necrosis in cervical cancer cells," Cancer Letters, vol. 271, no. 1, pp. 34-46, 2008.

[27] J. Zhao, S. Kang, X. Zhang et al., "Apoptotic activity of a new jasmonate analogue is associated with its induction of DNA damage," Oncology Reports, vol. 24, no. 3, pp. 771-777, 2010.

[28] E. Milrot, A. Jackman, T. Kniazhanski, P. Gonen, E. Flescher, and L. Sherman, "Methyl jasmonate reduces the survival of cervical cancer cells and downregulates HPV E6 and E7, and survivin," Cancer Letters, vol. 319, no. 1, pp. 31-38, 2012.

[29] E. Milrot, A. Jackman, E. Flescher et al., "Enhanced killing of cervical cancer cells by combinations of methyl jasmonate with cisplatin, X or alpha radiation," Investigational New Drugs, vol. 31, no. 2, pp. 333-344, 2013.

[30] N. Goldin, L. Arzoine, A. Heyfets et al., "Methyl jasmonate binds to and detaches mitochondria-bound hexokinase," Oncogene, vol. 27, no. 34, pp. 4636-4643, 2008. 
[31] J. Ávila-Román, E. Talero, C. de los Reyes Jiménez et al., "Methyl jasmonate is a promising tool against colon cáncer," in Proceedings of the 6th European Congress of Pharmacology, 2012.

[32] Z. Raviv, A. Zilberberg, S. Cohen et al., "Methyl jasmonate down-regulates survivin expression and sensitizes colon carcinoma cells towards TRAIL-induced cytotoxicity," British Journal of Pharmacology, vol. 164, no. 5, pp. 1433-1444, 2011.

[33] L. Zheng, D. Li, X. Xiang et al., "Methyl jasmonate abolishes the migration, invasion and angiogenesis of gastric cancer cells through down-regulation of matrix metalloproteinase 14," BMC Cancer, vol. 13, article 74, 2013.

[34] C. Park, C.-Y. Jin, G.-Y. Kim et al., "A methyl jasmonate derivative, J-7, induces apoptosis in human hepatocarcinoma Hep3B cells in vitro," Toxicology in Vitro, vol. 24, no. 7, pp. 19201926, 2010.

[35] C. Park, C.-Y. Jin, H. J. Hwang et al., "J7, a methyl jasmonate derivative, enhances TRAIL-mediated apoptosis through upregulation of reactive oxygen species generation in human hepatoma HepG2 cells," Toxicology in Vitro, vol. 26, no. 1, pp. 86-93, 2012.

[36] J. H. Kim, S. Y. Lee, S. Y. Oh et al., "Methyl jasmonate induces apoptosis through induction of Bax/Bcl-XS and activation of caspase-3 via ROS production in A549 cells," Oncology Reports, vol. 12, no. 6, pp. 1233-1238, 2004.

[37] L. Yeruva, K. J. Pierre, S. W. Carper, J. A. Elegbede, B. J. Toy, and R. C. Wang, "Jasmonates induce apoptosis and cell cycle arrest in non-small cell lung cancer lines," Experimental Lung Research, vol. 32, no. 10, pp. 499-516, 2006.

[38] R. Rotem, A. Heyfets, O. Fingrut, D. Blickstein, M. Shaklai, and E. Flescher, "Jasmonates: novel anticancer agents acting directly and selectively on human cancer cell mitochondria," Cancer Research, vol. 65, no. 5, pp. 1984-1993, 2005.

[39] D. Reischer, A. Heyfets, S. Shimony, J. Nordenberg, Y. Kashman, and E. Flescher, "Effects of natural and novel synthetic jasmonates in experimental metastatic melanoma," British Journal of Pharmacology, vol. 150, no. 6, pp. 738-749, 2007.

[40] J. E. F. Pereira Lopes, M. R. Barbosa, C. N. Stella et al., "In vivo anti-angiogenic effects further support the promise of the antineoplasic activity of methyl jasmonate," Brazilian Journal of Biology, vol. 70, no. 2, pp. 443-449, 2010.

[41] Y. Ishii, H. Kiyota, S. Sakai, and Y. Honma, "Induction of differentiation of human myeloid leukemia cells by jasmonates, plant hormones," Leukemia, vol. 18, no. 8, pp. 1413-1419, 2004.

[42] H. Tsumura, M. Akimoto, H. Kiyota, Y. Ishii, H. Ishikura, and Y. Honma, "Gene expression profiles in differentiating leukemia cells induced by methyl jasmonate are similar to those of cytokinins and methyl jasmonate analogs induce the differentiation of human leukemia cells in primary culture," Leukemia, vol. 23, no. 4, pp. 753-760, 2009.

[43] G.-S. Jiang, Q.-S. Tong, F.-Q. Zeng et al., "Methyl jasmonate induces apoptosis of human neuroblastoma cell line BE(2)-C and its mechanism," Yaoxue Xuebao, vol. 43, no. 6, pp. 584-590, 2008.

[44] Q.-S. Tong, G.-S. Jiang, L.-D. Zheng et al., "Natural jasmonates of different structures suppress the growth of human neuroblastoma cell line SH-SY5Y and its mechanisms," Acta Pharmacologica Sinica, vol. 29, no. 7, pp. 861-869, 2008.

[45] Q.-S. Tong, G.-S. Jiang, L.-D. Zheng et al., "Methyl jasmonate downregulates expression of proliferating cell nuclear antigen and induces apoptosis in human neuroblastoma cell lines," AntiCancer Drugs, vol. 19, no. 6, pp. 573-581, 2008.
[46] D. Samaila, D. E. Ezekwudo, K. K. Yimam, and J. A. Elegbede, "Bioactive plant compounds inhibited the proliferation and induced apoptosis in human cancer cell lines, in vitro," Transactions of the Integrated Bio-Medical Informatics \& Enabling Technologies Symposiums, vol. 1, pp. 34-42, 2004.

[47] D. E. Ezekwudo, R. C. Wang, and J. A. Elegbede, "Methyl jasmonate induced apoptosis in human prostate carcinoma cells via 5-lipoxygenase dependent pathway," Journal of Experimental Therapeutics and Oncology, vol. 6, no. 4, pp. 267-277, 2007.

[48] L. Yeruva, K. J. Pierre, M. Bathina, A. Elegbede, and S. W. Carper, "Delayed cytotoxic effects of methyl jasmonate and cisjasmone induced apoptosis in prostate cancer cells," Cancer Investigation, vol. 26, no. 9, pp. 890-899, 2008.

[49] U. Elia and E. Flescher, "PI3K/Akt pathway activation attenuates the cytotoxic effect of methyl jasmonate toward sarcoma cells," Neoplasia, vol. 10, no. 11, pp. 1303-1313, 2008.

[50] J. Scognamiglio, L. Jones, C. S. Letizia, and A. M. Api, "Fragrance material review on methyl jasmonate," Food and Chemical Toxicology, vol. 50, supplement 3, pp. S572-S576, 2012.

[51] B. Palmieri, T. Iannitti, S. Capone, and E. Flescher, "A preliminary study of the local treatment of preneoplastic and malignant skin lesions using methyl jasmonate," European Review for Medical and Pharmacological Sciences, vol. 15, no. 3, pp. 333336, 2011.

[52] Environmental Protection Agency (EPA), "Methyl Jasmonate: exemption from the requirement of a tolerance," Federal Register, vol. 78, no. 74, pp. 22789-22794, 2013.

[53] J. A. Pietenpol and Z. A. Stewart, "Cell cycle checkpoint signaling: cell cycle arrest versus apoptosis," Toxicology, vol. 181182, pp. 475-481, 2002.

[54] S. van den Heuvel, "Cell-cycle regulation," in WormBook, The C. elegans Research Community, WormBook, 2005.

[55] K. Vermeulen, Z. N. Berneman, and D. R. Van Bockstaele, "Cell cycle and apoptosis," Cell Proliferation, vol. 36, no. 3, pp. 165-175, 2003.

[56] D. Reisman, P. Takahashi, A. Polson, and K. Boggs, “Transcriptional regulation of the p53 tumor suppressor gene in S-phase of the cell-cycle and the cellular response to DNA damage," Biochemistry Research International, vol. 2012, Article ID 808934, 5 pages, 2012.

[57] E. H. Verbon, J. A. Post, and J. Boonstra, "The influence of reactive oxygen species on cell cycle progression in mammalian cells," Gene, vol. 511, no. 1, pp. 1-6, 2012.

[58] J. Watson, "Oxidants, antioxidants and the current incurability of metastatic cancers," Open Biology, vol. 3, no. 1, Article ID 120144, 2013.

[59] L. Soucek, J. Whitfield, C. P. Martins et al., "Modelling Myc inhibition as a cancer therapy," Nature, vol. 455, no. 7213, pp. 679-683, 2008.

[60] A. K. Jain, K. Allton, M. Iacovino et al., "P53 regulates cell cycle and micrornas to promote differentiation of human embryonic stem cells," PLoS Biology, vol. 10, no. 2, Article ID e1001268, 2012.

[61] M. R. Chorawala, P. M. Oza, and G. B. Shah, "Mechanisms of anticancer drugs resistance: an overview," International Journal of Pharmaceutical Sciences and Drug Research, vol. 4, no. 1, pp. $1-9,2012$.

[62] Y.-A. Suh, S. M. Post, A. C. Elizondo-Fraire et al., "Multiple stress signals activate mutant p53 in vivo," Cancer Research, vol. 71, no. 23, pp. 7168-7175, 2011.

[63] K. Kuribayashi, N. Finnberg, J. R. Jeffers, G. P. Zambetti, and W. S. El-Deiry, "The relative contribution of pro-apoptotic 
p53-target genes in the triggering of apoptosis following DNA damage in vitro and in vivo," Cell Cycle, vol. 10, no. 14, pp. 23802389, 2011.

[64] A. M. Puzio-Kuter, "The role of p53 in metabolic regulation," Genes and Cancer, vol. 2, no. 4, pp. 385-391, 2011.

[65] K. Suzuki and H. Matsubara, "Recent advances in p53 research and cancer treatment," Journal of Biomedicine and Biotechnology, vol. 2011, Article ID 978312, 7 pages, 2011.

[66] M. J. Grossel and P. W. Hinds, "From cell cycle to differentiation: an expanding role for Cdk6," Cell Cycle, vol. 5, no. 3, pp. 266270, 2006.

[67] R. G. Jones and C. B. Thompson, "Tumor suppressors and cell metabolism: a recipe for cancer growth," Genes and Development, vol. 23, no. 5, pp. 537-548, 2009.

[68] M. Olivier, M. Hollstein, and P. Hainaut, “TP53 mutations in human cancers: origins, consequences, and clinical use," Cold Spring Harbor Perspectives in Biology, vol. 2, no. 1, Article ID a001008, 2010.

[69] A. Maillet and S. Pervaiz, "Redox regulation of p53, redox effectors regulated by p53: a subtle balance," Antioxidants and Redox Signaling, vol. 16, no. 11, pp. 1285-1294, 2012.

[70] A. A. Sablina, A. V. Budanov, G. V. Ilyinskaya, L. S. Agapova, J. E. Kravchenko, and P. M. Chumakov, "The antioxidant function of the p53 tumor suppressor," Nature Medicine, vol. 11, no. 12, pp. 1306-1313, 2005.

[71] E. Gottlieb and K. H. Vousden, "P53 regulation of metabolic pathways," Cold Spring Harbor Perspectives in Biology, vol. 2, no. 4, Article ID a001040, 2010.

[72] P.-F. Li, R. Dietz, and R. von Harsdorf, "P53 regulates mitochondrial membrane potential through reactive oxygen species and induces cytochrome c-independent apoptosis blocked by Bcl2," EMBO Journal, vol. 18, no. 21, pp. 6027-6036, 1999.

[73] B. Liu, P53 and reactive oxygen species: a convoluted story [M.S. thesis], University of Kentucky, 2007, http://uknowledge.uky.edu/gradschool_theses/450/.

[74] J. M. Rae, C. J. Creighton, J. M. Meck, B. R. Haddad, and M. D. Johnson, "MDA-MB-435 cells are derived from M14 Melanoma cells-a loss for breast cancer, but a boon for melanoma research," Breast Cancer Research and Treatment, vol. 104, no. 1, pp. 13-19, 2007.

[75] H. Berglind, Y. Pawitan, S. Kato, C. Ishioka, and T. Soussi, "Analysis of p53 mutation status in human cancer cell lines: a paradigm for cell line cross-contamination," Cancer Biology \& Therapy, vol. 7, no. 5, pp. 699-708, 2008.

[76] E. S. Nejad, H. Askari, and S. Soltani, "Regulatory TGACGmotif may elicit the secondary metabolite production through inhibition of active Cyclin-dependent kinase/Cyclin complex," Plant Omics Journal, vol. 5, no. 6, pp. 553-558, 2012.

[77] L. Pauwels, K. Morreel, E. De Witte et al., "Mapping methyl jasmonate-mediated transcriptional reprogramming of metabolism and cell cycle progression in cultured Arabidopsis cells," Proceedings of the National Academy of Sciences of the United States of America, vol. 105, no. 4, pp. 1380-1385, 2008.

[78] C. V. Dang, "MYC on the path to cancer," Cell, vol. 149, no. 1, pp. 22-35, 2012.

[79] G. Nestal de Moraes, K. L. Silva, F. D. C. Vasconcelos, and R. C. Maia, "Survivin overexpression correlates with an apoptosisresistant phenotype in chronic myeloid leukemia cells," Oncology Reports, vol. 25, no. 6, pp. 1613-1619, 2011.

[80] A. Rahman, T. Sultan, and R. Islam, "Apoptosis and cancer: insights molecular mechanisms and treatments," International
Journal of Biomolecules \& Biomedicine, vol. 2, no. 1, pp. 1-16, 2012.

[81] D.-F. Suen, K. L. Norris, and R. J. Youle, "Mitochondrial dynamics and apoptosis," Genes and Development, vol. 22, no. 12, pp. 1577-1590, 2008.

[82] G. Kroemer, L. Galluzzi, and C. Brenner, "Mitochondrial membrane permeabilization in cell death," Physiological Reviews, vol. 87, no. 1, pp. 99-163, 2007.

[83] T. Bender and G. C. Martinou, "Where killers meetpermeabilization of the outer mitochondrial membrane during apoptosis," Cold Spring Harbor Perspectives in Biology, vol. 5, no. 1, Article ID a011106, 2013.

[84] M. H. Kang and C. P. Reynolds, "BcI-2 inhibitors: targeting mitochondrial apoptotic pathways in cancer therapy," Clinical Cancer Research, vol. 15, no. 4, pp. 1126-1132, 2009.

[85] R. Kumarswamy and S. Chandna, "Putative partners in Bax mediated cytochrome-c release: ANT, CypD, VDAC or none of them?" Mitochondrion, vol. 9, no. 1, pp. 1-8, 2009.

[86] S. S. Roy, M. Madesh, E. Davies, B. Antonsson, N. Danial, and G. Hajnóczky, "Bad targets the permeability transition pore independent of Bax or Bak to switch between $\mathrm{Ca} 2^{+}$-dependent cell survival and death," Molecular Cell, vol. 33, no. 3, pp. 377388, 2009.

[87] S. Shimizu, M. Narita, and Y. Tsujimoto, "Bcl-2 family proteins regulate the release of apoptogenic cytochrome $\mathrm{c}$ by the mitochondrial channel VDAC," Nature, vol. 399 , no. 6735, pp. 483487, 1999.

[88] E. H.-Y. Cheng, T. V. Sheiko, J. K. Fisher, W. J. Craigen, and S. J. Korsmeyer, "VDAC2 inhibits BAK activation and mitochondrial apoptosis," Science, vol. 301, no. 5632, pp. 513517, 2003.

[89] C. P. Baines, R. A. Kaiser, T. Sheiko, W. J. Craigen, and J. D. Molkentin, "Voltage-dependent anion channels are dispensable for mitochondrial-dependent cell death," Nature Cell Biology, vol. 9, no. 5, pp. 550-555, 2007.

[90] P. Kreuzaler and C. J. Watson, "Killing a cancer: what are the alternatives?" Nature Reviews Cancer, vol. 12, no. 6, pp. 411-424, 2012.

[91] N. Rivlin, R. Brosh, M. Oren, and V. Rotter, "Mutations in the p53 tumor suppressor gene: important milestones at the various steps of tumorigenesis," Genes and Cancer, vol. 2, no. 4, pp. 466474, 2011.

[92] K. H. Vousden and C. Prives, "Blinded by the light: the growing complexity of p53," Cell, vol. 137, no. 3, pp. 413-431, 2009.

[93] H. Wang, K. Luo, L. Z. Tan et al., "P53-induced gene 3 mediates cell death induced by glutathione peroxidase 3," The Journal of Biological Chemistry, vol. 287, no. 20, pp. 16890-16902, 2012.

[94] T. Ozaki and A. Nakagawara, "P53: the attractive tumor suppressor in the cancer research field," Journal of Biomedicine and Biotechnology, vol. 2011, Article ID 603925, 13 pages, 2011.

[95] M. Kracikova, G. Akiri, A. George, R. Sachidanandam, and S. A. Aaronson, "A threshold mechanism mediates p53 cell fate decision between growth arrest and apoptosis," Cell Death \& Differentiation, vol. 20, no. 4, pp. 576-588, 2013.

[96] S. Fulda and G. Kroemer, "Mitochondria as therapeutic targets for the treatment of malignant disease," Antioxidants and Redox Signaling, vol. 15, no. 12, pp. 2937-2949, 2011.

[97] J. Honeychurch, W. Alduaij, M. Azizyan et al., "Antibodyinduced nonapoptotic cell death in human lymphoma and leukemia cells is mediated through a novel reactive oxygen species-dependent pathway," Blood, vol. 119, no. 15, pp. 35233533, 2012. 
[98] J. D. Lambeth, "NOX enzymes and the biology of reactive oxygen," Nature Reviews Immunology, vol. 4, no. 3, pp. 181-189, 2004.

[99] D. G. Deavall, E. A. Martin, J. M. Horner, and R. Roberts, "Druginduced oxidative stress and toxicity," Journal of Toxicology, vol. 2012, Article ID 645460, 13 pages, 2012.

[100] J. Verrax, N. Dejeans, B. Sid, C. Glorieux, and P. B. Calderon, "Intracellular ATP levels determine cell death fate of cancer cells exposed to both standard and redox chemotherapeutic agents," Biochemical Pharmacology, vol. 82, no. 11, pp. 1540-1548, 2011.

[101] N. Festjens, T. Vanden Berghe, and P. Vandenabeele, "Necrosis, a well-orchestrated form of cell demise: signalling cascades, important mediators and concomitant immune response," Biochimica et Biophysica Acta, vol. 1757, no. 9-10, pp. 1371-1387, 2006.

[102] K. M. Irrinki, K. Mallilankaraman, R. J. Thapa et al., "Requirement of FADD, NEMO, and BAX/BAK for aberrant mitochondrial function in tumor necrosis factor alpha-induced necrosis," Molecular and Cellular Biology, vol. 31, no. 18, pp. 3745-3758, 2011.

[103] P. Vandenabeele, L. Galluzzi, T. Vanden Berghe, and G. Kroemer, "Molecular mechanisms of necroptosis: an ordered cellular explosion," Nature Reviews Molecular Cell Biology, vol. 11, no. 10, pp. 700-714, 2010.

[104] D. Ezekwudo, R. Shashidharamurthy, D. Devineni, E. Bozeman, R. Palaniappan, and P. Selvaraj, "Inhibition of expression of anti-apoptotic protein $\mathrm{Bcl}-2$ and induction of cell death in radioresistant human prostate adenocarcinoma cell line (PC-3) by methyl jasmonate," Cancer Letters, vol. 270, no. 2, pp. 277$285,2008$.

[105] S. Klippel, J. Jakubikova, J. Delmore et al., "Methyl jasmonate displays in vitro and in vivo activity against multiple myeloma cells," British Journal of Haematology, vol.159, no. 3, pp. 340-351, 2012.

[106] G. Manda, M. T. Nechifor, and T.-M. Neagu, "Reactive oxygen species, cancer and anti-cancer therapies," Current Chemical Biology, vol. 3, no. 1, pp. 22-46, 2009.

[107] M. S. Wolin, M. Ahmad, and S. A. Gupte, "Oxidant and redox signaling in vascular oxygen sensing mechanisms: basic concepts, current controversies, and potential importance of cytosolic NADPH," American Journal of Physiology-Lung Cellular and Molecular Physiology, vol. 289, no. 2, pp. L159-L173, 2005.

[108] M. Ushio-Fukai, "Localizing NADPH oxidase-derived ROS," Science's STKE, vol. 2006, no. 349, article re8, 2006.

[109] K. Chen, S. E. Craige, and J. F. Keaney Jr., "Downstream targets and intracellular compartmentalization in Nox signaling," Antioxidants \& Redox Signaling, vol. 11, no. 10, pp. 2467-2480, 2009.

[110] C. E. Paulsen and K. S. Carroll, "Orchestrating redox signaling networks through regulatory cysteine switches," ACS Chemical Biology, vol. 5, no. 1, pp. 47-62, 2010.

[111] K. Wejksza, C. Lee-Chang, M. Bodogai et al., "Cancer-produced metabolites of 5-lipoxygenase induce tumor-evoked regulatory B cells via peroxisome proliferator-activated receptor alpha," The Journal of Immunology, vol. 190, no. 6, pp. 2575-2584, 2013.

[112] A. J. Lambert and M. D. Brand, "Reactive oxygen species production by mitochondria," Methods in Molecular Biology, vol. 554, pp. 165-181, 2009.

[113] M. Malinouski, Y. Zhou, V. V. Belousov, D. L. Hatfield, and V. N. Gladyshev, "Hydrogen peroxide probes directed to different cellular compartments," PLoS ONE, vol. 6, no. 1, Article ID e14564, 2011.

[114] S. S. Korshunov, V. P. Skulachev, and A. A. Starkov, "High protonic potential actuates a mechanism of production of reactive oxygen species in mitochondria," FEBS Letters, vol. 416, no. 1 , pp. 15-18, 1997.

[115] J. F. Turrens, "Mitochondrial formation of reactive oxygen species," Journal of Physiology, vol. 552, no. 2, pp. 335-344, 2003.

[116] M. Le Bras, M.-V. Clément, S. Pervaiz, and C. Brenner, "Reactive oxygen species and the mitochondrial signaling pathway of cell death," Histology and Histopathology, vol. 20, no. 1, pp. 205-219, 2005.

[117] A. Chatterjee, S. Dasgupta, and D. Sidransky, "Mitochondrial subversion in cancer," Cancer Prevention Research, vol. 4, no. 5, pp. 638-654, 2011.

[118] W. Ladiges, J. Wanagat, B. Preston, L. Loeb, and P. Rabinovitch, "A mitochondrial view of aging, reactive oxygen species and metastatic cancer," Aging Cell, vol. 9, no. 4, pp. 462-465, 2010.

[119] E. Anso, A. R. Mullen, D. W. Felsher, J. M. Matés, R. J. DeBerardinis, and N. S. Chandel, "Metabolic changes in cancer cells upon suppression of MYC," Cancer \& Metabolism, vol. 1, article 7, 2013.

[120] S. J. Ralph, S. Rodríguez-Enríquez, J. Neuzil, E. Saavedra, and R. Moreno-Sánchez, "The causes of cancer revisited: "mitochondrial malignancy" and ROS-induced oncogenic transformation-why mitochondria are targets for cancer therapy," Molecular Aspects of Medicine, vol. 31, no. 2, pp. 145-170, 2010.

[121] W. Bechtel and G. Bauer, "Catalase protects tumor cells from apoptosis induction by intercellular ROS signaling," Anticancer Research, vol. 29, no. 11, pp. 4541-4557, 2009.

[122] S. J. Ralph, S. Rodríguez-Enríquez, J. Neuzil, and R. MorenoSánchez, "Bioenergetic pathways in tumor mitochondria as targets for cancer therapy and the importance of the ROSinduced apoptotic trigger," Molecular Aspects of Medicine, vol. 31, no. 1, pp. 29-59, 2010.

[123] T. Ozben, "Oxidative stress and apoptosis: impact on cancer therapy," Journal of Pharmaceutical Sciences, vol. 96, no. 9, pp. 2181-2196, 2007.

[124] A. K. Maiti, "Reactive oxygen species reduction is a key underlying mechanism of drug resistance in cancer chemotherapy," Chemotherapy, vol. 1, pp. 104-108, 2012.

[125] V. Loyola-Vargas, E. Ruiz-May, R. Galaz-Avalos, and C. Dela-Pena, "The role of jasmonic acid in root mitochondria disruption," Plant Signaling \& Behavior, vol. 7, no. 6, pp. 611-614, 2012.

[126] M. L. Orozco-Cárdenas, J. Narváez-Vásquez, and C. A. Ryan, "Hydrogen peroxide acts as a second messenger for the induction of defense genes in tomato plants in response to wounding, systemin, and methyl jasmonate," Plant Cell, vol. 13, no. 1, pp. 179-191, 2001.

[127] G. P. Bienert, J. K. Schjoerring, and T. P. Jahn, "Membrane transport of hydrogen peroxide," Biochimica et Biophysica Acta, vol. 1758, no. 8, pp. 994-1003, 2006.

[128] K. T. Hung, Y. T. Hsu, and C. H. Kao, "Hydrogen peroxide is involved in methyl jasmonate-induced senescence of rice leaves," Physiologia Plantarum, vol. 127, no. 2, pp. 293-303, 2006.

[129] F. C. Küpper, E. Gaquerel, A. Cosse et al., "Free fatty acids and methyl jasmonate trigger defense reactions in laminaria digitata," Plant and Cell Physiology, vol. 50, no. 4, pp. 789-800, 2009. 
[130] S. Y. Oh, J. H. Kim, M. J. Park et al., "Induction of heat shock protein 72 in C6 glioma cells by methyl jasmonate through ROS-dependent heat shock factor 1 activation," International Journal of Molecular Medicine, vol. 16, no. 5, pp. 833-839, 2005.

[131] M. López-Lázaro, "Increase in the $\Delta \psi_{m}$ produced either by a closure of the mitochondrial permeability transition pore or by inhibition of the ATP synthase," Cancer Letts, vol. 252, pp. 1-8, 2007.

[132] N. J. Davies, R. E. Hayden, P. J. Simpson et al., "AKR1C isoforms represent a novel cellular target for jasmonates alongside their mitochondrial-mediated effects," Cancer Research, vol. 69, no. 11, pp. 4769-4775, 2009.

[133] V. Fritz and L. Fajas, "Metabolism and proliferation share common regulatory pathways in cancer cells," Oncogene, vol. 29, no. 31, pp. 4369-4377, 2010.

[134] O. Warburg, "On respiratory impairment in cancer cells," Science, vol. 124, no. 3215, pp. 269-270, 1956.

[135] S. P. Mathupala, Y. H. Ko, and P. L. Pedersen, "The pivotal roles of mitochondria in cancer: warburg and beyond and encouraging prospects for effective therapies," Biochimica et Biophysica Acta, vol. 1797, no. 6-7, pp. 1225-1230, 2010.

[136] M. L. Turcotte, H. Parliament, A. Franko, and J. AllalunisTurner, "Variation in mitochondrial function in hypoxiasensitive and hypoxia-tolerant human glioma cells," British Journal of Cancer, vol. 86, no. 4, pp. 619-624, 2002.

[137] C. E. Griguer, C. R. Oliva, and G. Y. Gillespie, "Glucose metabolism heterogeneity in human and mouse malignant glioma cell lines," Journal of Neuro-Oncology, vol. 74, no. 2, pp. 123-133, 2005.

[138] A. Wolf, S. Agnihotri, and A. Guha, "Targeting metabolic remodeling in glioblastoma multiforme," Oncotarget, vol. 1, no. 7, pp. 552-562, 2010.

[139] R. Majeed, A. Hamid, Y. Qurishi et al., “Therapeutic targeting of cancer cell metabolism: role of metabolic enzymes, oncogenes and tumor suppressor genes," Journal of Cancer Science \& Therapy, vol. 4, no. 9, pp. 281-291, 2012.

[140] J. E. Wilson, "Isozymes of mammalian hexokinase: structure, subcellular localization and metabolic function," Journal of Experimental Biology, vol. 206, no. 12, pp. 2049-2057, 2003.

[141] S. John, J. N. Weiss, and B. Ribalet, "Subcellular localization of hexokinases I and II directs the metabolic fate of glucose," PLoS ONE, vol. 6, no. 3, Article ID el7674, 2011.

[142] S. P. Mathupala, Y. H. Ko, and P. L. Pedersen, "Hexokinase-2 bound to mitochondria: cancer's stygian link to the "Warburg effect" and a pivotal target for effective therapy," Seminars in Cancer Biology, vol. 19, no. 1, pp. 17-24, 2009.

[143] P. L. Pedersen, S. Mathupala, A. Rempel, J. F. Geschwind, and Y. $\mathrm{H}$. Ko, "Mitochondrial bound type II hexokinase: a key player in the growth and survival of many cancers and an ideal prospect for therapeutic intervention," Biochimica et Biophysica Acta, vol. 1555, no. 1-3, pp. 14-20, 2002.

[144] R. A. Nakashima, P. S. Mangan, M. Colombini, and P. L. Pedersen, "Hexokinase receptor complex in hepatoma mitochondria: evidence from $\mathrm{N}, \mathrm{N}^{\prime}$-dicyclohexylcarbodiimide-labeling studies for the involvement of the pore-forming protein VDAC," Biochemistry, vol. 25, no. 5, pp. 1015-1021, 1986.

[145] P. L. Pedersen, "Voltage dependent anion channels (VDACs): a brief introduction with a focus on the outer mitochondrial compartment's roles together with hexokinase-2 in the "Warburg effect" in cancer," Journal of Bioenergetics and Biomembranes, vol. 40, no. 3, pp. 123-126, 2008.
[146] R. P. Gonçalves, N. Buzhysnskyy, and S. Scheuring, "Mini review on the structure and supramolecular assembly of VDAC," Journal of Bioenergetics and Biomembranes, vol. 40, no. 3, pp. 133-138, 2008.

[147] V. Shoshan-Barmatz and D. Mizrachi, "VDACl: from structure to cancer therapy," Frontiers in Oncology, vol. 2, article 146, 2012.

[148] C. Grills, P. V. Jithesh, J. Blayney, S.-D. Zhang, and D. A. Fennell, "Gene expression meta-analysis identifies VDAC1 as a predictor of poor outcome in early stage non-small cell lung cancer," PLoS ONE, vol. 6, no. 1, Article ID e14635, 2011.

[149] L. Galluzzi, O. Kepp, N. Tajeddine, and G. Kroemer, "Disruption of the hexokinase-VDAC complex for tumor therapy," Oncogene, vol. 27, no. 34, pp. 4633-4635, 2008.

[150] P. L. Pedersen, "Warburg, me and Hexokinase 2: multiple discoveries of key molecular events underlying one of cancers' most common phenotypes, the "Warburg Effect", i.e., elevated glycolysis in the presence of oxygen," Journal of Bioenergetics and Biomembranes, vol. 39, no. 3, pp. 211-222, 2007.

[151] J. J. Lemasters and E. Holmuhamedov, "Voltage-dependent anion channel (VDAC) as mitochondrial governator-thinking outside the box," Biochimica et Biophysica Acta, vol. 1762, no. 2, pp. 181-190, 2006.

[152] R. J. Mailloux, T. Dumouchel, C. Aguer, R. Dekemp, R. Beanlands, and M.-E. Harper, "Hexokinase II acts through UCP3 to suppress mitochondrial reactive oxygen species production and maintain aerobic respiration," Biochemical Journal, vol. 437, no. 2, pp. 301-311, 2011.

[153] K. J. Ahn, J. Kim, M. Yun, J. H. Park, and J. D. Lee, "Enzymatic properties of the $\mathrm{N}$-and $\mathrm{C}$-terminal halves of human hexokinase II," BMB Reports, vol. 42, no. 6, pp. 350-355, 2009.

[154] N. Majewski, V. Nogueira, R. B. Robey, and N. Hay, "Akt inhibits apoptosis downstream of BID cleavage via a glucose-dependent mechanism involving mitochondrial hexokinases," Molecular and Cellular Biology, vol. 24, no. 2, pp. 730-740, 2004.

[155] R. L. Elstrom, D. E. Bauer, M. Buzzai et al., "Akt stimulates aerobic glycolysis in cancer cells," Cancer Research, vol. 64, no. 11, pp. 3892-3899, 2004.

[156] J. G. Pastorino, J. B. Hoek, and N. Shulga, "Activation of glycogen synthase kinase $3 \beta$ disrupts the binding of hexokinase II to mitochondria by phosphorylating voltage-dependent anion channel and potentiates chemotherapy-induced cytotoxicity," Cancer Research, vol. 65, no. 22, pp. 10545-10554, 2005.

[157] C. Martel, M. Allouche, D. D. Esposti et al., "GSK3-mediated VDAC phosphorylation controls outer mitochondrial membrane permeability during lipid accumulation," Hepatology, vol. 57, no. 1, pp. 93-102, 2012.

[158] C. L. Neary and J. G. Pastorino, "Akt inhibition promotes hexokinase 2 redistribution and glucose uptake in cancer cells," Journal of Cellular Physiology, vol. 228, no. 9, pp. 1943-1948, 2013.

[159] J. G. Pastorino and J. B. Hoek, "Hexokinase II: the integration of energy metabolism and control of apoptosis," Current Medicinal Chemistry, vol. 10, no. 16, pp. 1535-1551, 2003.

[160] S. P. Mathupala, Y. H. Ko, and P. L. Pedersen, "Hexokinase II: cancer's double-edged sword acting as both facilitator and gatekeeper of malignancy when bound to mitochondria," Oncogene, vol. 25, no. 34, pp. 4777-4786, 2006.

[161] D. B. Zorov, M. Juhaszova, Y. Yaniv, H. B. Nuss, S. Wang, and S. J. Sollott, "Regulation and pharmacology of the mitochondrial permeability transition pore," Cardiovascular Research, vol. 83, no. 2, pp. 213-225, 2009. 
[162] G. Kroemer and J. Pouyssegur, "Tumor cell metabolism: cancer's Achilles' heel," Cancer Cell, vol. 13, no. 6, pp. 472-482, 2008.

[163] S. Fulda, L. Galluzzi, and G. Kroemer, "Targeting mitochondria for cancer therapy," Nature Reviews Drug Discovery, vol. 9, no. 6, pp. 447-464, 2010.

[164] A. Wolf, S. Agnihotri, J. Micallef et al., "Hexokinase 2 is a key mediator of aerobic glycolysis and promotes tumor growth in human glioblastoma multiforme," Journal of Experimental Medicine, vol. 208, no. 2, pp. 313-326, 2011.

[165] E. C. Cheung, R. L. Ludwig, and K. H. Vousden, "Mitochondrial localization of TIGAR under hypoxia stimulates HK2 and lowers ROS and cell death," Proceedings of the National Academy of Sciences, vol. 109, no. 50, pp. 20491-20496, 2012.

[166] A. L. Simons, I. M. Ahmad, D. M. Mattson, K. J. Dornfeld, and D. R. Spitz, "2-Deoxy-D-glucose combined with cisplatin enhances cytotoxicity via metabolic oxidative stress in human head and neck cancer cells," Cancer Research, vol. 67, no. 7, pp. 3364-3370, 2007.

[167] L. S. Ihrlund, E. Hernlund, O. Khan, and M. C. Shoshan, "3Bromopyruvate as inhibitor of tumour cell energy metabolism and chemopotentiator of platinum drugs," Molecular Oncology, vol. 2, no. 1, pp. 94-101, 2008.

[168] W. Kim, J.-H. Yoon, J.-M. Jeong et al., "Apoptosis-inducing antitumor efficacy of hexokinase II inhibitor in hepatocellular carcinoma," Molecular Cancer Therapeutics, vol. 6, no. 9, pp. 2554-2562, 2007.

[169] F. Chiara, D. Castellaro, O. Marin et al., "Hexokinase II detachment from mitochondria triggers apoptosis through the permeability transition pore independent of voltage-dependent anion channels," PLoS ONE, vol. 3, no. 3, Article ID e1852, 2008.

[170] A. Heyfets and E. Flescher, "Cooperative cytotoxicity of methyl jasmonate with anti-cancer drugs and 2-deoxy-d-glucose," Cancer Letters, vol. 250, no. 2, pp. 300-310, 2007.

[171] T. Thalhamer, M. A. McGrath, and M. M. Harnett, "MAPKs and their relevance to arthritis and inflammation," Rheumatology, vol. 47, no. 4, pp. 409-414, 2008.

[172] S. Tamura, M. Hanada, M. Ohnishi, K. Katsura, M. Sasaki, and T. Kobayashi, "Regulation of stress-activated protein kinase signaling pathways by protein phosphatases," European Journal of Biochemistry, vol. 269, no. 4, pp. 1060-1066, 2002.

[173] H. Ichijo, E. Nishida, K. Irie et al., "Induction of apoptosis by ASK1, a mammalian MAPKKK that activates SAPK/JNK and p38 signaling pathways," Science, vol. 275, no. 5296, pp. 90-94, 1997.

[174] Y. T. Ip and R. J. Davis, "Signal transduction by the c-Jun Nterminal kinase (JNK) - from inflammation to development," Current Opinion in Cell Biology, vol. 10, no. 2, pp. 205-219, 1998.

[175] Y. Shi and M. Gaestel, "In the cellular garden of forking paths: how p38 MAPKs signal for downstream assistance," Biological Chemistry, vol. 383, no. 10, pp. 1519-1536, 2002.

[176] J. H. Weisburg, "Multidrug resistance in acute myeloid leukemia: potential new therapeutics," Journal of Nuclear Medicine, vol. 49, no. 9, pp. 1405-1407, 2008.

[177] G. Trinchieri, "Innate inflammation and cancer: is it time for cancer prevention?" F1000 Medicine Reports, vol. 3, no. 1, article $11,2011$.

[178] H. T. Dang, H. J. Lee, E. S. Yoo et al., "New jasmonate analogues as potential anti-inflammatory agents," Bioorganic and Medicinal Chemistry, vol. 16, no. 24, pp. 10228-10235, 2008.

[179] H.-J. Lee, K. Maeng, H.-T. Dang et al., "Anti-inflammatory effect of methyl dehydrojasmonate (J2) is mediated by the NF- $\kappa \mathrm{B}$ pathway," Journal of Molecular Medicine, vol. 89, no. 1, pp. 83-90, 2011.

[180] H. Ohnishi, N. Miyahara, and E. W. Gelfand, "The role of leukotriene B4 in allergic diseases," Allergology International, vol. 57, no. 4, pp. 291-298, 2008.

[181] V. Mugoni and M. M. Santoro, "Manipulating redox signaling to block tumor angiogenesis," in Research Directions in Tumor Angiogenesis, chapter 3, pp. 47-72, 2013.

[182] D. X. Nguyen, P. D. Bos, and J. Massagué, "Metastasis: from dissemination to organ-specific colonization," Nature Reviews Cancer, vol. 9, no. 4, pp. 274-284, 2009.

[183] Y. Jin and T. M. Penning, "Aldo-keto reductases and bioactivation/detoxication," Annual Review of Pharmacology and Toxicology, vol. 47, pp. 263-292, 2007.

[184] K. Matsuura, H. Shiraishi, A. Hara et al., "Identification of a principal mRNA species for human $3 \alpha$-hydroxysteroid dehydrogenase isoform (AKR1C3) that exhibits high prostaglandin D2 11-ketoreductase activity," Journal of Biochemistry, vol. 124, no. 5, pp. 940-946, 1998.

[185] T. M. Penning and J. E. Drury, "Human aldo-keto reductases: function, gene regulation, and single nucleotide polymorphisms," Archives of Biochemistry and Biophysics, vol. 464, no. 2, pp. 241-250, 2007.

[186] T. Matsunaga, Y. Wada, S. Endo, M. Soda, O. El-Kabbani, and A. Hara, "Aldo-keto reductase 1B10 and its role in proliferation capacity of drug-resistant cancers," Frontiers in Pharmacology, vol. 3, article 5, 2012.

[187] N.-Y. Hsu, H.-C. Ho, K.-C. Chow et al., "Overexpression of dihydrodiol dehydrogenase as a prognostic marker of nonsmall cell lung cancer," Cancer Research, vol. 61, no. 6, pp. 27272731, 2001.

[188] P. Vihko, A. Herrala, P. Härkönen et al., "Enzymes as modulators in malignant transformation," Journal of Steroid Biochemistry and Molecular Biology, vol. 93, no. 2-5, pp. 277-283, 2005.

[189] H.-L. Tai, T.-S. Lin, H.-H. Huang et al., "Overexpression of aldo-keto reductase $1 \mathrm{C} 2$ as a high-risk factor in bladder cancer," Oncology Reports, vol. 17, no. 2, pp. 305-311, 2007.

[190] H. B. Deng, H. K. Parekh, K.-C. Chow, and H. Simpkins, "Increased expression of dihydrodiol dehydrogenase induces resistance to cisplatin in human ovarian carcinoma cells," The Journal of Biological Chemistry, vol. 277, no. 17, pp. 15035-15043, 2002.

[191] Y.-J. Chen, C.-C. Yuan, K.-C. Chow et al., "Overexpression of dihydrodiol dehydrogenase is associated with cisplatinbased chemotherapy resistance in ovarian cancer patients," Gynecologic Oncology, vol. 97, no. 1, pp. 110-117, 2005.

[192] W. D. Chen and Y. Zhang, "Regulation of aldo-keto reductases in human diseases," Frontiers in Pharmacology, vol. 3, article 35, 2012.

[193] W. Ax, M. Soldan, L. Koch, and E. Maser, "Development of daunorubicin resistance in tumour cells by induction of carbonyl reduction," Biochemical Pharmacology, vol. 59, no. 3, pp. 293-300, 2000.

[194] E. K. Lee, W. T. Regenold, and P. Shapiro, "Inhibition of aldose reductase enhances Hela cell sensitivity to chemotherapeutic drugs and involves activation of extracellular signal-regulated kinases," Anti-Cancer Drugs, vol. 13, no. 8, pp. 859-868, 2002.

[195] M. Maccarrone, "Lipoxygenases, apoptosis, and the role of antioxidants," in Photoprotection, Photoinhibition, Gene Regulation, and Environment, vol. 21 of Advances in Photosynthesis and Respiration, pp. 321-332, 2008. 
[196] A. R. Brash, "Lipoxygenases: occurrence, functions, catalysis, and acquisition of substrate," The Journal of Biological Chemistry, vol. 274, no. 34, pp. 23679-23682, 1999.

[197] M. C. Meyer, P. Rastogi, C. S. Beckett, and J. McHowat, "Phospholipase A2 inhibitors as potential anti-inflammatory agents," Current Pharmaceutical Design, vol. 11, no. 10, pp. 13011312, 2005.

[198] M. M. Bosma-den Boer, M.-L. van Wetten, and L. Pruimboom, "Chronic inflammatory diseases are stimulated by current lifestyle: how diet, stress levels and medication prevent our body from recovering," Nutrition \& Metabolism, vol. 9, article 32, 2012.

[199] O. Werz, J. Klemm, B. Samuelsson, and O. Rådmark, "5Lipoxygenase is phosphorylated by p38 kinase-dependent MAPKAP kinases," Proceedings of the National Academy of Sciences of the United States of America, vol. 97, no. 10, pp. 52615266, 2000.

[200] W.-G. Tong, X.-Z. Ding, R. C. Witt, and T. E. Adrian, "Lipoxygenase inhibitors attenuate growth of human pancreatic cancer xenografts and induce apoptosis through the mitochondrial pathway," Molecular Cancer Therapeutics, vol. 1, no. 11, pp. 929935, 2002.

[201] W.-G. Tong, X.-Z. Ding, and T. E. Adrian, “The mechanisms of lipoxygenase inhibitor-induced apoptosis in human breast cancer cells," Biochemical and Biophysical Research Communications, vol. 296, no. 4, pp. 942-948, 2002.

[202] Y.-N. Ye, E. S.-L. Liu, V. Y. Shin, W. K.-K. Wu, and C.-H. Cho, "Contributory role of 5-lipoxygenase and its association with angiogenesis in the promotion of inflammation-associated colonic tumorigenesis by cigarette smoking," Toxicology, vol. 203, no. 1-3, pp. 179-188, 2004.

[203] W.-G. Tong, X.-Z. Ding, M. S. Talamonti, R. H. Bell, and T. E. Adrian, "LTB4 stimulates growth of human pancreatic cancer cells via MAPK and PI-3 kinase pathways," Biochemical and Biophysical Research Communications, vol. 335, no. 3, pp. 949956, 2005.

[204] J. Ghosh and C. E. Myers, "Arachidonic acid stimulates prostate cancer cell growth: critical role of 5-lipoxygenase," Biochemical and Biophysical Research Communications, vol. 235, no. 2, pp. 418-423, 1997.

[205] J. T. O'Flaherty, L. C. Rogers, B. A. Chadwell et al., “5(S)hydroxy-6,8,11,14-E,Z,Z,Z-eicosatetraenoate stimulates PC3 cell signaling and growth by a receptor-dependent mechanism," Cancer Research, vol. 62, no. 23, pp. 6817-6819, 2002.

[206] Y.-N. Ye, E. S.-L. Liu, V. Y. Shin, W. K.-K. Wu, and C.-H. Cho, "Contributory role of 5-lipoxygenase and its association with angiogenesis in the promotion of inflammation-associated colonic tumorigenesis by cigarette smoking," Toxicology, vol. 203, no. 1-3, pp. 179-188, 2004.

[207] K. M. Anderson, T. Seed, M. Vos et al., "5-Lipoxygenase inhibitors reduce PC-3 cell proliferation and initiate nonnecrotic cell death," Prostate, vol. 37, no. 3, pp. 161-173, 1998.

[208] I. Avis, S. H. Hong, A. Martinez et al., "Five-lipoxygenase inhibitors can mediate apoptosis in human breast cancer cell lines through complex eicosanoid interactions," The FASEB Journal, vol. 15, no. 11, pp. 2007-2009, 2001.

[209] X. M. Fan, S. P. Tu, S. K. Lam et al., "Five-lipoxygenaseactivating protein inhibitor MK-886 induces apoptosis in gastric cancer through upregulation of p27kipl and bax," Journal of Gastroenterology and Hepatology, vol. 19, no. 1, pp. 31-37, 2004.

[210] M. Kovarikova, J. Hofmanova, K. Soucek, and A. Kozubik, "The effects of TNF-alpha and inhibitors of arachidonic acid metabolism on human colon HT-29 cells depend on differentiation status," Differentiation, vol. 72, no. 1, pp. 23-31, 2004.

[211] A. Hoque, S. M. Lippman, T.-T. Wu et al., "Increased 5lipoxygenase expression and induction of apoptosis by its inhibitors in esophageal cancer: a potential target for prevention," Carcinogenesis, vol. 26, no. 4, pp. 785-791, 2005.

[212] X. Chen, S. Sood, C. S. Yang, N. Li, and Z. Sun, "Fivelipoxygenase pathway of arachidonic acid metabolism in carcinogenesis and cancer chemoprevention," Current Cancer Drug Targets, vol. 6, no. 7, pp. 613-622, 2006.

[213] S. Gupta, M. Strivastva, N. Ahmad, K. Sakamoto, D. G. Bostwick, and H. Muktar, "Lipoxygenase- 5 is overexpressed in prostate adenocarcinoma," Cancer, vol. 91, pp. 737-743, 2001.

[214] R. Yoshimura, M. Matsuyama, K. Tsuchida, Y. Kawahito, H. Sano, and T. Nakatani, "Expression of lipoxygenase in human bladder carcinoma and growth inhibition by its inhibitors," Journal of Urology, vol. 170, no. 5, pp. 1994-1999, 2003.

[215] H. Zhi, J. Zhang, G. Hu et al., "The deregulation of arachidonic acid metabolism-related genes in human esophageal squamous cell carcinoma," International Journal of Cancer, vol. 106, no. 3, pp. 327-333, 2003.

[216] R. Hennig, X.-Z. Ding, W.-G. Tong et al., "5-Lipoxygenase and leukotriene B4 receptor are expressed in human pancreatic cancers but not in pancreatic ducts in normal tissue," American Journal of Pathology, vol. 161, no. 2, pp. 421-428, 2002.

[217] L.-Y. Zou, J.-Y. Li, F.-L. Chen, Z.-X. Chen, and X.-Z. Wang, "Tumor 5-lipoxygenase expression correlates with gastric cancer metastasis and its selective inhibitor induces cancer cell apoptosis," Journal of Cancer Molecules, vol. 2, no. 6, pp. 227233, 2006.

[218] M. Romano, A. Catalano, M. Nutini et al., "5-Lipoxygenase regulates malignant mesothelial cell survival: involvement of vascular endothelial growth factor," The FASEB Journal, vol. 15, no. 13, pp. 2326-2336, 2001.

[219] I. M. Avis, M. Jett, T. Boyle et al., "Growth control of lung cancer by interruption of 5-lipoxygenase-mediated growth factor signaling," The Journal of Clinical Investigation, vol. 97, no. 3, pp. 806-813, 1996.

[220] R. J. Boado, W. M. Pardridge, H. V. Vinters, and K. L. Black, "Differential expression of arachidonate 5-lipoxygenase transcripts in human brain tumors: evidence for the expression of a multitranscript family," Proceedings of the National Academy of Sciences of the United States of America, vol. 89, no. 19, pp. 9044-9048, 1992.

[221] C. V. Rao, A. Rivenson, B. Simi et al., "Chemoprevention of colon carcinogenesis by sulindac, a nonsteroidal anti- inflammatory agent," Cancer Research, vol. 55, no. 7, pp. 1464-1472, 1995.

[222] X.-M. Xu, J.-J. Deng, G.-J. Yuan et al., "5-Lipoxygenase contributes to the progression of hepatocellular carcinoma," Molecular Medicine Reports, vol. 4, no. 6, pp. 1195-1200, 2011.

[223] B. Sveinbjörnsson, A. Rasmuson, N. Baryawno et al., "Expression of enzymes and receptors of the leukotriene pathway in human neuroblastoma promotes tumor survival and provides a target for therapy," The FASEB Journal, vol. 22, no. 10, pp. 35253536, 2008.

[224] L. T. Soumaoro, S. Iida, H. Uetake et al., "Expression of 5lipoxygenase in human colorectal cancer," World Journal of Gastroenterology, vol. 12, no. 39, pp. 6355-6360, 2006.

[225] K. Ishii, M. Zaitsu, N. Yonemitsu, Y. Kan, Y. Hamasaki, and M. Matsuo, "5-lipoxygenase pathway promotes cell proliferation in 
human glioma cell lines," Clinical Neuropathology, vol. 28, no. 6, pp. 445-452, 2009.

[226] P. C. Boger, J. D. Shutt, and J. R. Neale, "Increased expression of the 5-lipoxygenase pathway and its cellular localization in Barrett's adenocarcinoma," Histopathology, vol. 61, pp. 509-517, 2012.

[227] Z. Sun, S. Sood, N. Li et al., "Involvement of the 5-lipoxygenase/leukotriene A4 hydrolase pathway in 7,12-dimethylbenz[a]anthracene (DMBA)-induced oral carcinogenesis in hamster cheek pouch, and inhibition of carcinogenesis by its inhibitors," Carcinogenesis, vol. 27, no. 9, pp. 1902-1908, 2006.

[228] R. C. Goupil, J. J. Bushey, J. Peters-Kennedy, and J. J. Wakshlag, "Prevalence of 5-lipoxygenase expression in canine osteosarcoma and the effects of a dual 5-lipoxygenase/cyclooxygenase inhibitor on osteosarcoma cells in vitro and in vivo," Veterinary Pathology, vol. 49, no. 5, pp. 802-810, 2012.

[229] H. J. Hussey and M. J. Tisdale, "Inhibition of tumour growth by lipoxygenase inhibitors," British Journal of Cancer, vol. 74, no. 5, pp. 683-687, 1996.

[230] X.-Z. Ding, P. Iversen, M. W. Cluck, J. A. Knezetic, and T. E. Adrian, "Lipoxygenase inhibitors abolish proliferation of human pancreatic cancer cells," Biochemical and Biophysical Research Communications, vol. 261, no. 1, pp. 218-223, 1999.

[231] A. S. Fischer, J. Metzner, S. D. Steinbrink et al., "5-Lipoxygenase inhibitors induce potent anti-proliferative and cytotoxic effects in human tumour cells independently of suppression of 5lipoxygenase activity," British Journal of Pharmacology, vol. 161, no. 4, pp. 936-949, 2010.

[232] J. Ghosh and C. E. Myers, "Inhibition of arachidonate 5lipoxygenase triggers massive apoptosis in human prostate cancer cells," Proceedings of the National Academy of Sciences of the United States of America, vol. 95, no. 22, pp. 13182-13187, 1998.

[233] T. A. Miller, J. Ghosh, C. E. Myers, and T. L. Macdonald, "5HETE congeners as modulators of cell proliferation," Bioorganic and Medicinal Chemistry Letters, vol. 10, no. 17, pp. 1913-1916, 2000.

[234] J. Ghosh, "Inhibition of arachidonate 5-lipoxygenase triggers prostate cancer cell death through rapid activation of c-Jun Nterminal kinase," Biochemical and Biophysical Research Communications, vol. 307, no. 2, pp. 342-349, 2003.

[235] M. Maccarrone, G. Melino, and A. Finazzi-Agrò, "Lipoxygenases and their involvement in programmed cell death," Cell Death and Differentiation, vol. 8, no. 8, pp. 776-784, 2001.

[236] M. Luo, S. Lee, and T. G. Brock, "Leukotriene synthesis by epithelial cells," Histology and Histopathology, vol. 18, no. 2, pp. 587-595, 2003.

[237] H. Hanaka, T. Shimizu, and T. Izumi, "Stress-induced nuclear export of 5-lipoxygenase," Biochemical and Biophysical Research Communications, vol. 338, no. 1, pp. 111-116, 2005.

[238] O. Werz and D. Steinhilber, "Therapeutic options for 5lipoxygenase inhibitors," Pharmacology and Therapeutics, vol. 112, no. 3, pp. 701-718, 2006.

[239] A. S. Fischer, J. Metzner, S. D. Steinbrink et al., "5-Lipoxygenase inhibitors induce potent anti-proliferative and cytotoxic effects in human tumour cells independently of suppression of 5lipoxygenase activity," British Journal of Pharmacology, vol. 161, no. 4, pp. 936-949, 2010.

[240] A. M. Bair, M. V. Turman, C. A. Vaine, R. A. Panettieri, and R. J. Soberman Jr., "The nuclear membrane leukotriene synthetic complex is a signal integrator and transducer," Molecular Biology of the Cell, vol. 23, no. 22, pp. 4456-4464, 2012.
[241] A. Russo, C. L. Espinoza, S. Caggia et al., "A new jasmonic acid stereoisomeric derivative induces apoptosis via reactive oxygen species in human prostate cancer cells," Cancer Letters, vol. 326, no. 2, pp. 199-205, 2012.

[242] L. J. Marnett, "Inflammation and cancer: chemical approaches to mechanisms, imaging, and treatment," The Journal of Organic Chemistry, vol. 77, no. 12, pp. 5224-5238, 2012.

[243] P. Pratheeshkumar, C. Sreekala, Z. Zhang et al., "Cancer prevention with promising natural products: mechanisms of action and molecular targets," Anti-Cancer Agents in Medicinal Chemistry, vol. 12, no. 10, pp. 1159-1184, 2012.

[244] E. L. Kwak, J. W. Clark, and B. Chabner, "Targeted agents: the rules of combination," Clinical Cancer Research, vol. 13, no. 18, pp. 5232-5237, 2007.

[245] G. Ghavami, M. R. Kazemali, and S. Sardari, "Informatics of drug synergism in naturally occurring anticancer agents," Recent Patents on Anti-Cancer Drug Discovery, vol. 6, no. 1, pp. 26-44, 2011.

[246] A. Mohan, S. Narayanan, S. Sethuraman, and U. M. Krishnan, "Combinations of plant polyphenols \& anti-cancer molecules: a novel treatment strategy for cancer chemotherapy," Anti-Cancer Agents in Medicinal Chemistry, vol. 13, no. 2, pp. 281-295, 2013.

[247] R. Takimoto, J. Kato, T. Terui et al., "Augmentation of antitumor effects of p53 gene therapy by combination with HDAC inhibitor," Cancer Biology and Therapy, vol. 4, no. 4, pp. 421428, 2005.

[248] B. S. Vinod, T. T. Maliekal, and R. J. Anto, "Phytochemicals as chemosensitizers: from molecular mechanism to clinical significance," Antioxidants \& Redox Signaling, vol. 18, no. 11, pp. 1307-1348, 2013.

[249] S. Cai, Y. Xu, R. J. Cooper et al., "Mitochondrial targeting of human O6-methylguanine DNA methyltransferase protects against cell killing by chemotherapeutic alkylating agents," Cancer Research, vol. 65, no. 8, pp. 3319-3327, 2005.

[250] W. P. Tsang, S. P. Y. Chau, S. K. Kong, K. P. Fung, and T. T. Kwok, "Reactive oxygen species mediate doxorubicin induced p53-independent apoptosis," Life Sciences, vol. 73, no. 16, pp. 2047-2058, 2003.

[251] L. Yeruva, C. Hall, J. A. Elegbede, and S. W. Carper, "Perillyl alcohol and methyl jasmonate sensitize cancer cells to cisplatin," Anti-Cancer Drugs, vol. 21, no. 1, pp. 1-9, 2010.

[252] A. Macciò and C. Madeddu, "Cisplatin: an old drug with a newfound efficacy-from mechanisms of action to cytotoxicity," Expert Opinion on Pharmacotherapy, vol. 14, no. 13, pp. 1839-1857, 2013.

[253] A. A. Farooqi, G. Butt, and Z. Razzaq, "Algae extracts and methyl jasmonate anti-cancer activities in prostate cancer: choreographers of 'the dance macabre," Cancer Cell International, vol. 12, article 50, 2012.

[254] X.-Y. Xiao, G.-S. Jiang, L. Wang, L. Lv, and F.-Q. Zeng, "Predominant enhancement of apoptosis induced by methyl jasmonate in bladder cancer cells: therapeutic effect of the Antpconjugated Smac peptide," Anti-Cancer Drugs, vol. 22, no. 9, pp. 853-863, 2011.

[255] G. Jiang, J. Zhao, X. Xiao et al., "AN N-terminal Smac peptide sensitizes human prostate carcinoma cells to methyl jasmonateinduced apoptosis," Cancer Letters, vol. 302, no. 1, pp. 37-46, 2011.

[256] C. C. G. Hernandes, S. C. França, A. L. Fachin, M. Marins, and M. V. Lourenço, "Cytotoxic effect of jasmonate and methyl jasmonate on a canine macrophage tumor cell line," A Revista Brasileira de Plantas Medicinais, vol. 14, no. 1, pp. 122-124, 2012. 

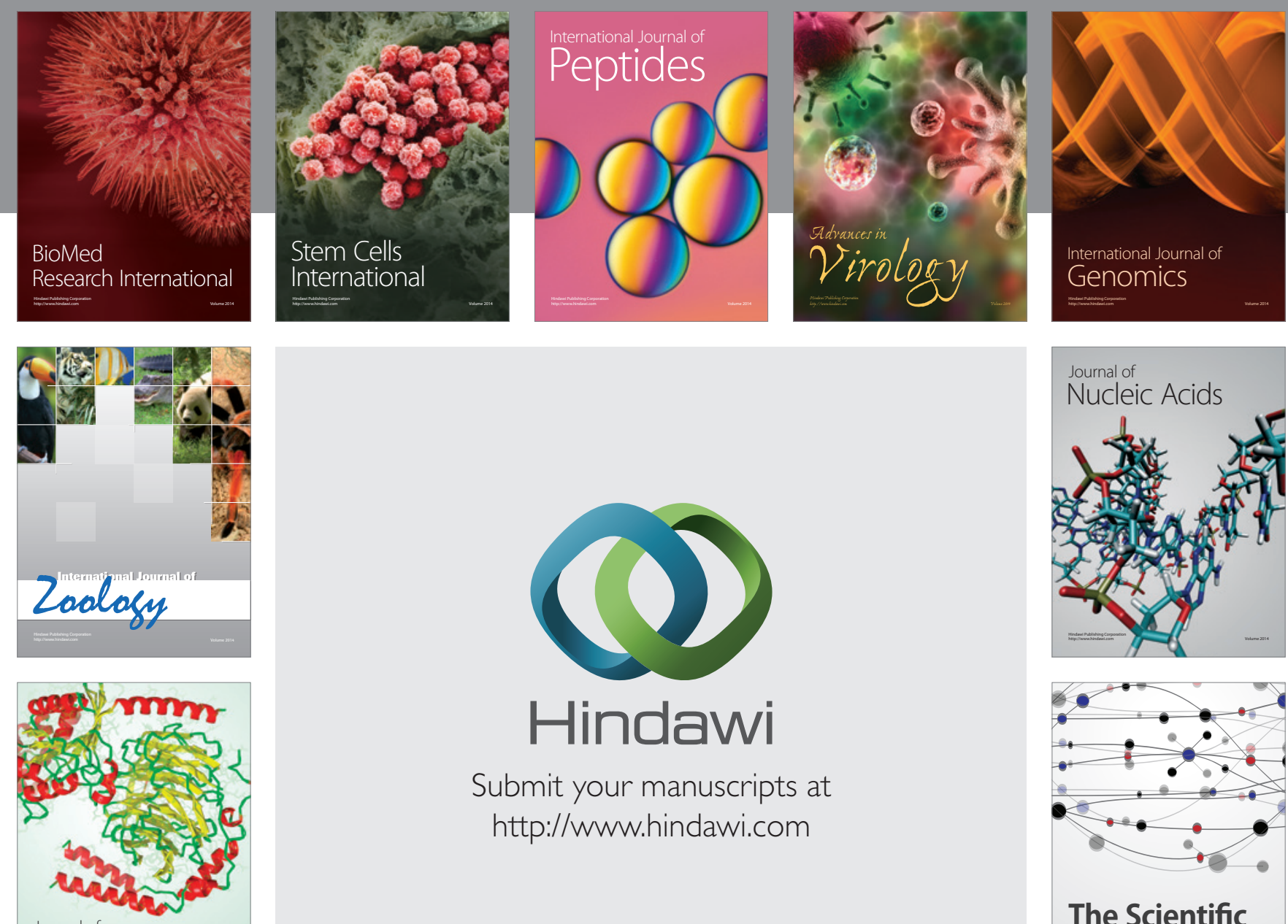

Submit your manuscripts at

http://www.hindawi.com

Journal of
Signal Transduction
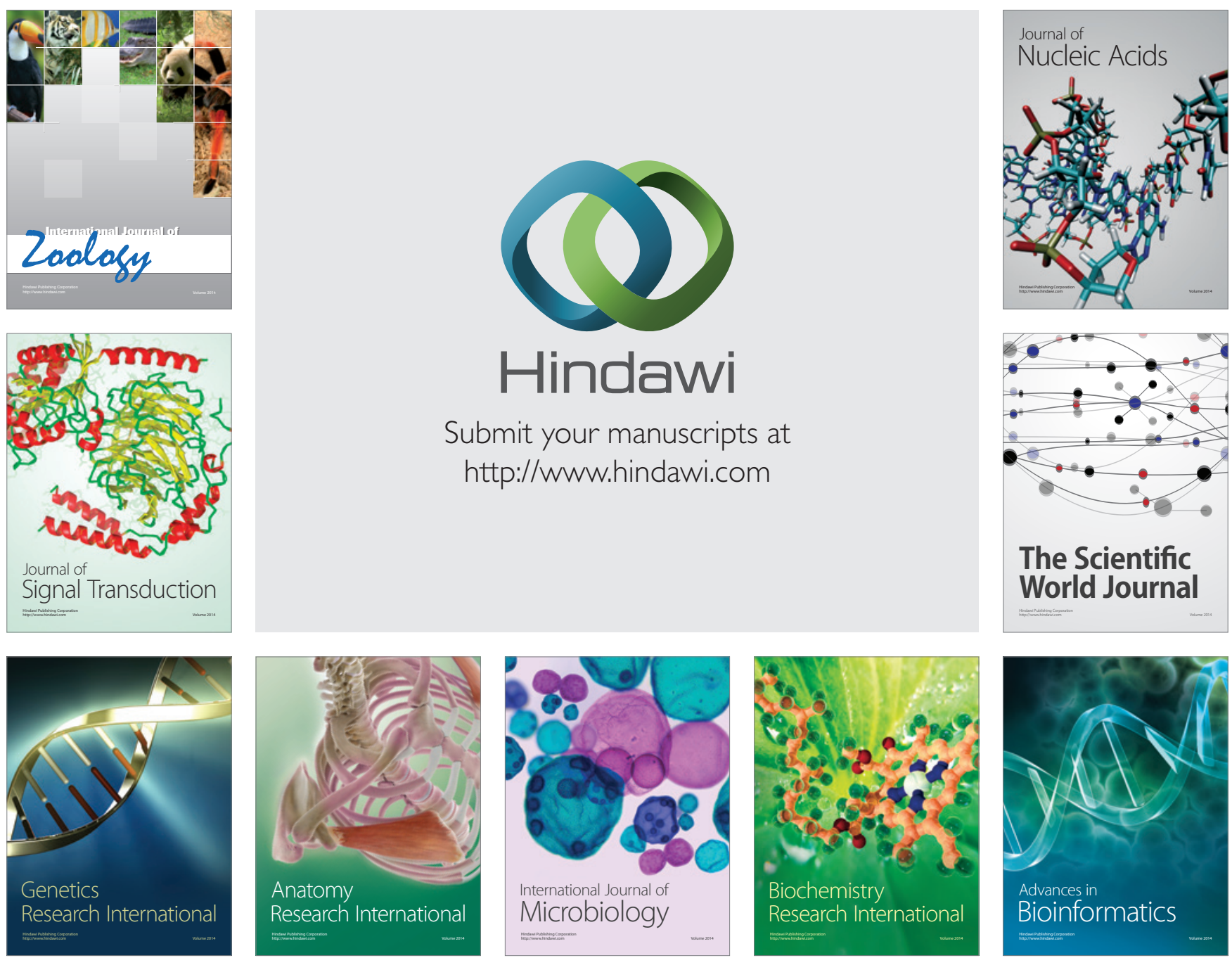

The Scientific World Journal
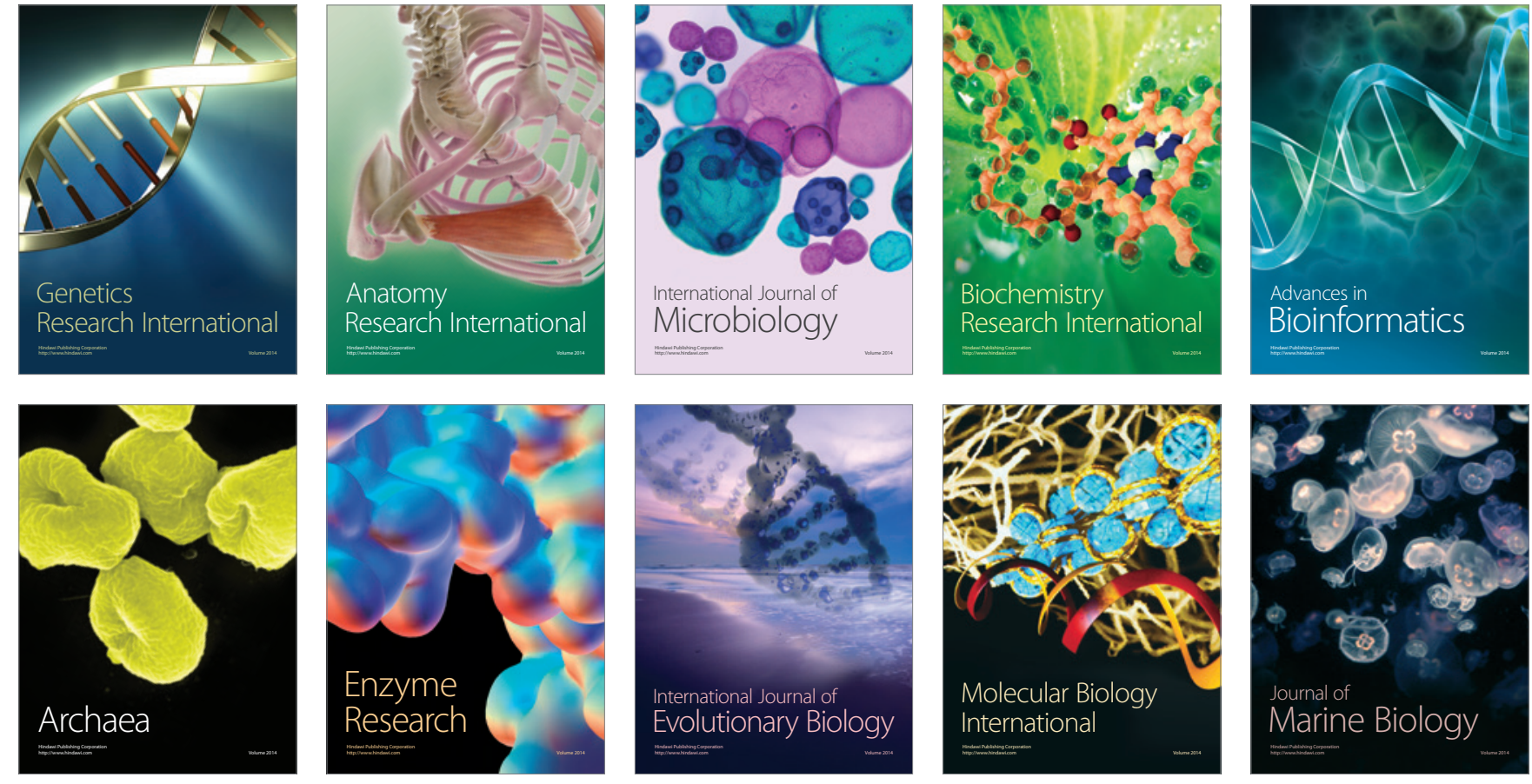